\title{
Benthic sulfate reduction along the Chesapeake Bay central channel. II. Temporal controls
}

\author{
M. C. Marvin-DiPasquale ${ }^{1, *}$, W. R. Boynton ${ }^{2}$, D. G. Capone ${ }^{3}$ \\ ${ }^{1}$ Water Resource Division, US Geological Survey, MS 480, 345 Middlefield Road, Menlo Park, California 94025, USA \\ ${ }^{2}$ Chesapeake Biological Laboratory, Center for Environmental Science, University of Maryland, 1 Williams St., Solomons, \\ Maryland 20688, USA \\ ${ }^{3}$ Department of Biological Sciences, University of Southern California, AHF107, Los Angeles, California 90089-0371, USA
}

\begin{abstract}
Seasonal and interannual controls of benthic sulfate reduction (SR) were examined at 3 sites (upper [UB], mid- [MB] and lower [LB] bay) along the Chesapeake Bay central channel, from early spring through fall, for 6 yr (1989 to 1994). The combined influences of temperature, sulfate, organic loading and bioturbation affected seasonal SR rates differently in the 3 regions. Consistently low SR rates at UB resulted from low overlying-water sulfate concentrations and the dominance of refractory organic terrestrial material. Combined seasonal variation in temperature and sulfate accounted for $50 \%$ of the annual variability in 0 to $2 \mathrm{~cm}$ depth interval SR rates, while sediment organic content had no significant seasonal influence. In contrast, MB and LB sites had high rates of SR fostered by high levels of overlying water $\mathrm{SO}_{4}{ }^{2-}$ and organic input dominated by labile phytoplankton detritus. New organic loading (measured as chl a) stimulated 0 to $2 \mathrm{~cm}$ SR during spring at both sites. Combined organic quantity (as particulate $\mathrm{C}$ and/or $\mathrm{N}$ ) and temperature accounted for $>75 \%$ of the variability in 0 to $2 \mathrm{~cm}$ SR at MB during spring and fall. Molecular diffusion supplied 25 to $45 \%$ of the $\mathrm{SO}_{4}{ }^{2-}$ needed to fuel 0 to $12 \mathrm{~cm}$ depth interval SR at $\mathrm{MB}$, with the balance presumably supplied by S-recycling. Interannual differences in summertime SR rates were linked to the extent of freshwater flow during spring, with high-flow years associated with high SR rates at UB and MB, and low rates at LB. The negative trend between benthic SR and river flow at LB may result from the upestuary transport of senescing organic matter in bottom water, which increases in the lower reach of the estuary with increasing freshwater inflow.
\end{abstract}

KEY WORDS: Sulfate reduction · Benthic metabolism $\cdot$ Sediment $\cdot$ Estuary $\cdot$ Chesapeake Bay

\section{INTRODUCTION}

Microbial sulfate reduction (SR) is a major pathway of organic matter mineralization in coastal marine and estuarine sediments (Jørgensen 1977, Capone \& Kiene 1988). Factors that impact SR rates include temperature (Abdollahi \& Nedwell 1979), electron donor and acceptor availability (Goldhaber \& Kaplan 1975, Boudreau \& Westrich 1984), organic matter quality (Westrich \& Berner 1984), sedimentation rate (Berner 1978), and bioturbation (Hines \& Jones 1985). While single-factor controls on SR have been extensively investigated, few studies have considered the interrelationships and interactions among factors as they mediate SR over various temporal and spatial scales. This is partially due to the limited number of appropriate long-term data sets. While a few notable exceptions exist for coastal marine (Martens \& Klump 1984, Crill \& Martens 1987, Moeslund et al. 1994), salt-marsh (King 1988), and lake (Sherman et al. 1994) systems, comparable investigations are lacking for estuaries.

The 1989-1994 National Science Foundation LandMargin Ecosystem Research (LMER) Program for the Chesapeake Bay represents one of the longest continuous multi-site records of estuarine benthic SR to date. In an earlier report (Marvin-DiPasquale \& Capone 1998), we considered how the above factors influenced the spatial variation in SR at 3 regionally 
distinct sites along the Bay's central axis. We concluded that SR was limited by organic C in the oligohaline and polyhaline regions of the Bay, and by organic $\mathrm{C}$ at the sediment surface and $\mathrm{SO}_{4}{ }^{2-}$ at depth in the mesohaline. The mechanisms of control varied regionally and were based on differences in the quality and quantity of organic matter deposited to the benthos, $\mathrm{SO}_{4}{ }^{2-}$ availability, bioturbation, overlying water $\mathrm{O}_{2}$ conditions, reduced-S reoxidation dynamics, and ironsulfide mineral formation. We now explore the temporal controls on SR in the LMER study, focusing on the monthly to seasonal timescales. We additionally consider the seasonal dynamics of $\mathrm{SO}_{4}{ }^{2-}$ diffusion versus sulfur recycling in fueling mesohaline $\mathrm{SR}$, and the interannual relationship between summertime SR rates and spring freshwater input in all 3 bay regions.

\section{MATERIALS AND METHODS}

Sampling. The 3 benthic sites (upper [UB], mid- $[\mathrm{MB}$ ] and lower [LB] bay) lie along the western slope of the central channel of the Chesapeake Bay main-stem (Fig. 1). The oligohaline UB site is strongly influenced by the input of terrestrial organic and inorganic matter from the Susquehanna River (Zimmerman \& Canuel 2001). Sediment at UB is bioturbated by a diverse community of bivalves and polychaetes, and is characterized as oxidized silty clay. Mesohaline MB sediment is organic-rich, sufidic, highly reducing, non-bioturbated for most of the year, and receives deposited organic matter as mostly autochthonous phytoplankton detritus (Zimmerman \& Canuel 2001). Polyhaline LB sediment is oxidized silty sand that is heavily bioturbated by the tubebuilding polycheate Chaetopterus variopedatus (Schaffner 1990) and other organisms, and receives organic matter primarily as phytoplankton detritus (Canuel \& Zimmerman 1999). Sites were sampled monthly from March to November (excluding October) during 1989 in order to discern overall monthly and seasonal trends. In subsequent years (1990 to 1994), 3 to 5 cruises were conducted per year, which included at least 1 spring, summer and fall sampling. Measurements in April and July were made every year.

Sulfate reduction and ancillary biogeochemical analysis. A detailed description of onboard sediment processing and subsequent laboratory analyses was

previously published (Marvin-DiPasquale \& Capone 1998). In brief, duplicate subcores (2.5 inner diameter $\times 20 \mathrm{~cm}$ ) were taken from a single larger sediment box core. Depth-integrated SR was measured throughout the top $12 \mathrm{~cm}$ of sediment (in $2 \mathrm{~cm}$ intervals) using the ${ }^{35} \mathrm{SO}_{4}{ }^{2-}$ radiotracer method (Jørgensen 1978a, Roden \& Tuttle 1993a). Four-hour incubations were conducted at in situ temperature and were initiated onboard within $2 \mathrm{~h}$ of sediment collection. Incubations were arrested with $10 \%$ zinc-acetate followed by freezing. Subsequently, both radiolabeled and non-radiolabeled reduced-S was collected via chromium-reduction acid distillation, and quantified via liquid scintillation counting and colorimetric spectrophotometry (Cline 1969), respectively.

The top 16 to $20 \mathrm{~cm}$ of sediment from a separate box core was sub-sampled at 0.5 to $2 \mathrm{~cm}$ intervals for porosity and total organic matter (TOM), the latter calculated as percent loss dry weight after combus- 
tion at $475^{\circ} \mathrm{C}$. Pore water was collected via centrifugation under anaerobic conditions and subsequently analyzed for $\mathrm{SO}_{4}{ }^{2-}$ and $\mathrm{Cl}^{-}$via ion chromatography with conductivity detection. Pore water from $\mathrm{MB}$ (only) was analyzed for free sulfide $\left(\Sigma \mathrm{H}_{2} \mathrm{~S}\right)$ (Cline 1969). Surface sediment (top $1 \mathrm{~cm}$ ) was sampled for particulate carbon (PC), particulate nitrogen (PN) and chl a. PC and PN were analyzed, after combustion to $\mathrm{CO}_{2}$ and $\mathrm{N}_{2}$ gas, via thermal conductivity detection with a Perkin-Elmer ${ }^{\mathrm{TM}}$ 240-XA elemental analyzer. Chl a was analyzed fluorometrically (Strickland \& Parsons 1972). Sediment redox $\left(E_{\mathrm{h}}\right)$ was measured via platinum electrode (Cowen \& Boynton 1996). Bottom-water dissolved $\mathrm{O}_{2}$, temperature and salinity were measured using a Seabird ${ }^{\mathrm{TM}}$ CTD or Hydrolab ${ }^{\mathrm{TM}} 4000$.

Temperature coefficient. An Arrhenius-like model (Marvin-DiPasquale \& Capone 1998) was used to investigate the apparent temperature influence on SR for different sites/seasons. The linear form of this model was fit to the SR and temperature data:

$$
\ln \left(\mathrm{SR}_{i}\right)=\left(-C_{\mathrm{t}} / \mathrm{R}\right) \times T^{-1}+\ln (\mathrm{A})
$$

where $\mathrm{SR}_{i}$ is the 0 to $2 \mathrm{~cm}\left(\mathrm{SR}_{2}\right)$ or 0 to $12 \mathrm{~cm}\left(\mathrm{SR}_{12}\right)$ depth-integrated rate $\left(\mathrm{mmol} \mathrm{SO}_{4}{ }^{2-} \mathrm{m}^{-2} \mathrm{~d}^{-1}\right), T$ is temperature $(\mathrm{K}), C_{\mathrm{t}}$ is the temperature coefficient $(\mathrm{kJ}$ $\left.\mathrm{mol}^{-1}\right), \mathrm{R}$ is the gas constant $\left(0.008314 \mathrm{~kJ} \mathrm{~mol}^{-1} \mathrm{~K}^{-1}\right)$, and $\mathrm{A}$ is a constant. Values of $C_{\mathrm{t}}$ and $\mathrm{A}$ were calculated from the linear-regression slope and $y$-intercept, respectively. The temperature coefficient $\left(C_{\mathrm{t}}\right)$ is analogous to the well-known Arrhenius activation energy $\left(E_{\mathrm{a}}\right)$. However, the latter is typically measured for a set of replicate samples incubated simultaneously at a range of experimentally fixed temperatures (Abdollahi \& Nedwell 1979). In contrast, $C_{\mathrm{t}}$ was calculated from SR rates measured throughout this study at various in situ temperatures.

Sulfate diffusion model for Site MB. The rate of $\mathrm{SO}_{4}{ }^{2-}$ diffusion into the sediment from the overlying water was calculated for each MB profile using Fick's 1st Law equation (Berner 1980):

$$
J_{\mathrm{s}}=-\phi \times D_{\mathrm{s}(T)} \times(\delta \mathrm{C} / \delta x)
$$

where $J_{\mathrm{s}}$ is the sediment diffusion flux (mmol $\mathrm{SO}_{4}{ }^{2-}$ $\left.\mathrm{cm}^{-2} \mathrm{~d}^{-1}\right), \phi$ is sediment porosity, $D_{\mathrm{s}(T)}$ is the whole sediment temperature corrected diffusion coefficient $\left(\mathrm{cm}^{2} \mathrm{~d}^{-1}\right), \delta \mathrm{C} / \delta \mathrm{x}$ is the 1 st partial derivative of the $\mathrm{SO}_{4}{ }^{2-}$ concentration with respect to depth, calculated as the linear-regression slope of $\mathrm{SO}_{4}{ }^{2-}$ versus depth data for the upper surface interval (linear portion, $\mathrm{n}$ $=3$ to 13 data points). An average $\mathrm{MB} \phi$ of 0.9 was used in all calculations. Values for $D_{\mathrm{s}(T)}$ were calculated using $D_{\mathrm{s}}=0.43 \mathrm{~cm}^{2} \mathrm{~d}^{-1}$ at $25^{\circ} \mathrm{C}$, which was previously measured at a nearby $(>0.5 \mathrm{~km})$ mesohaline site (R64E) (Roden \& Tuttle 1992) using the ${ }^{35} \mathrm{SO}_{4}{ }^{2-}$ instantaneous source technique (Jørgensen 1978b), and assuming the relationship:

$$
D_{\mathrm{s}(T)}=0.43\left(D_{(T)}^{\circ}\right)\left(D_{(25)}^{\circ}\right)^{-1}
$$

where $D^{\circ}{ }_{(T)}$ and $D^{\circ}{ }_{(25)}\left(\right.$ in $\mathrm{cm}^{2} \mathrm{~s}^{-1}$ ) are the infinite dilution diffusion coefficients at temperature $T^{\circ} \mathrm{C}$ and $25^{\circ} \mathrm{C}$, respectively, and were calculated from data given in Li \& Gregory (1974) by Krom \& Berner (1980):

$$
D_{(T)}^{\circ}=10.7+0.23(T-25)
$$

Data analysis. Quantitative seasonal analysis was conducted by grouping data into the following 3 mo intervals: spring $=$ March to May, summer $=$ June to August, and fall = September to November. A grouping designated YEAR was used for the complete sampling period (March to November). Commercial software (S-Plus and Microsoft Excel) was used for all statistical tests, with accepted error set at $p<0.05$ in all cases, unless otherwise indicated. The response of SR to the combined effect of temperature and a second controlling factor was assessed by a linear multipleregression model of the generalized form:

$$
\mathrm{SR}=f(T, X)=(a \times T)+(b \times X)+\mathrm{C}
$$

where $a$ and $b$ are coefficients, $c$ is a constant, the independent variable $T$ is temperature $\left({ }^{\circ} \mathrm{C}\right), X$ is one of the following: $\mathrm{SO}_{4}{ }^{2-}, \mathrm{PC}, \mathrm{PN}, \mathrm{PC}: \mathrm{PN}$ ratio, chl $a$, or TOM. This model assumed that SR was linearly dependent on each independent variable, and that $T$ and $X$ were independent of each other.

The interannual variation in SR was investigated with respect to the $7 \mathrm{yr}$ (1987 to 1994) record of monthly averaged Susquehanna River flow data (USGS 1987-1994). Linear-regression analysis was used, with July $\mathrm{SR}_{2}$ as the dependent variable and time-averaged river flow (prior to July) as the independent variable. The timing and duration of river flow that most affected SR was determined by varying the time-window used for averaging river flow data, both in terms of size (1 to 9 mo averages) and initiation period (October of the preceding year to June of the same year). Months from the preceding year (October to December) were included to determine whether a 'memory effect' of autotrophic production from the previous fall was carried over to the following year. Previously published July $1987 \mathrm{SR}_{2}$ data (Roden \& Tuttle 1993a) from Sites R64 and LB3 (located $<1 \mathrm{~km}$ from Sites $\mathrm{MB}$ and LB, respectively) were included to increase the number of observations in these Bay regions. The interannual-comparison data set included an exceptionally high $\mathrm{SR}_{2}$ value measured at UB during July 1993 (at least 12× greater than all other values measured at UB), although this datum was excluded from all other calculations and monthly-seasonal comparisons. 


\section{RESULTS}

\section{Monthly and seasonal trends}

SR rates

The complete 1989 to 1994 Chesapeake Bay LMER database of depth-integrated $\mathrm{SR}_{12}$ has been previously published (Marvin-DiPasquale \& Capone 1998). Presented here as monthly averaged depth profiles, the rise and fall of SR rates at $\mathrm{MB}$ and $\mathrm{LB}$, throughout the composite year, is clearly illustrated (Fig. 2). UB rates were low throughout the year $\left(<100 \mathrm{nmol} \mathrm{SO}_{4}{ }^{2-} \mathrm{cm}^{-3}\right.$ $\mathrm{d}^{-1}$ at all depths), essentially vertical with depth during spring and October/November, and exhibited a slight increase with depth below $2 \mathrm{~cm}$ from June through

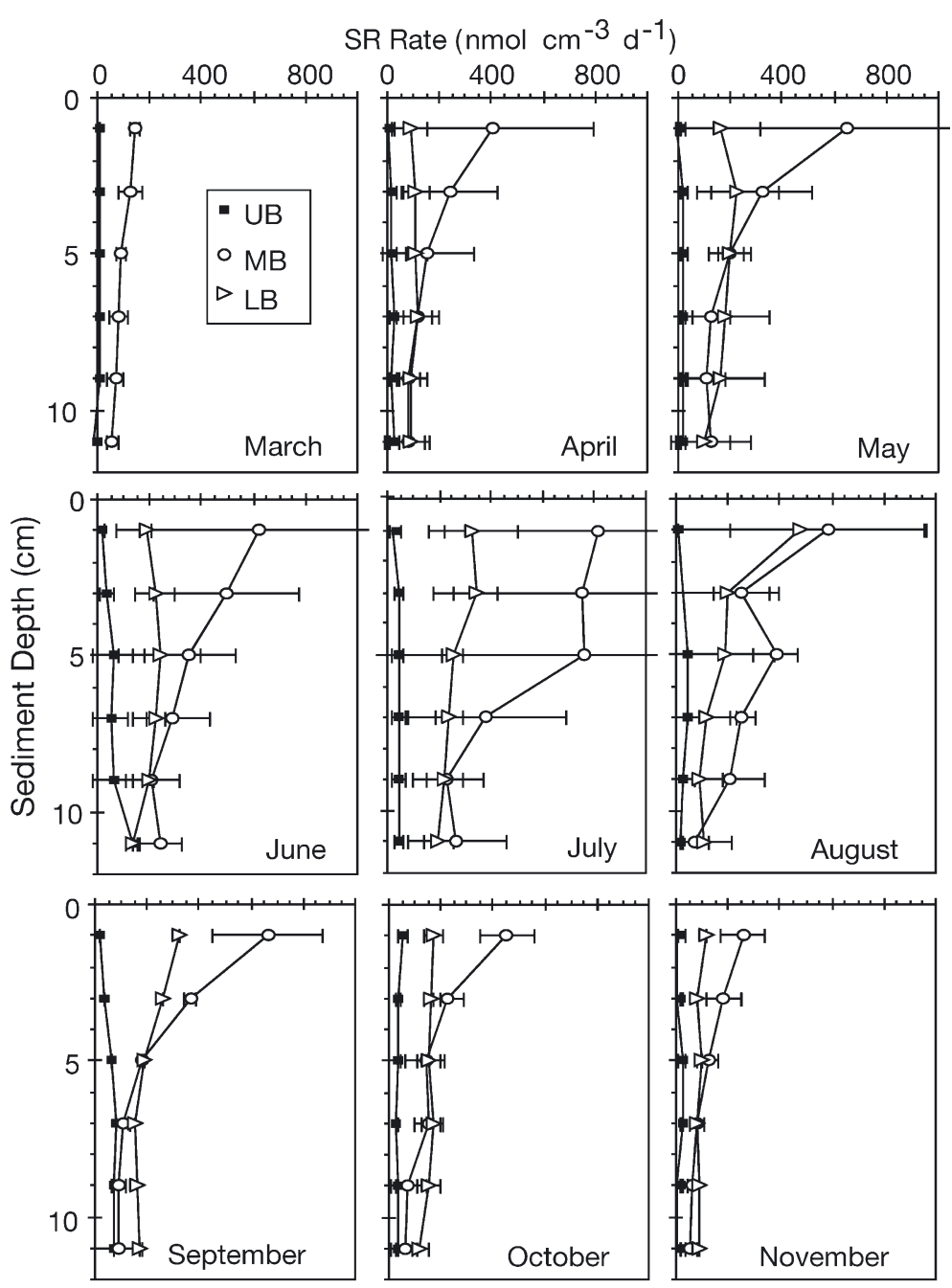

Fig. 2. Monthly average of all (1989 to 1994) sulfate reduction (SR) rate depth profile data for the 3 study sites (upper [UB], mid- [MB] and lower [LB] bay). The $y$-axis depicts the mid-point depth for each $2 \mathrm{~cm}$ interval.

Each point represents $n=1$ to 7 observations. Error bars represent either the absolute range (where $n=2$ ) or \pm 1 SD (where $n \geq 3$ )
September. In contrast, MB rates decreased sharply with depth from late spring through fall, with peak $\mathrm{SR}_{2}$ (>800 nmol $\mathrm{SO}_{4}{ }^{2-} \mathrm{Cm}^{-3} \mathrm{~d}^{-1}$ ) during July. LB exhibited elevated $\mathrm{SR}_{2}$ during August and September (480 and $370 \mathrm{nmol} \mathrm{SO}_{4}{ }^{2-} \mathrm{cm}^{-3} \mathrm{~d}^{-1}$, respectively), but were essentially constant with depth $\left(<300 \mathrm{nmol} \mathrm{SO}{ }^{2-} \mathrm{cm}^{-3} \mathrm{~d}^{-1}\right)$ throughout the remainder of the year. Depthintegrated monthly $\mathrm{SR}_{12}$ rates similarly exhibit differences among sites with respect to the magnitude of temporal variation, which was greatest at $\mathrm{MB}$ and smallest at UB, as the absolute difference between maximum and minimum monthly $\mathrm{SR}_{12}$ rates was 6 (UB), 58 (MB) and $21 \mathrm{mmol} \mathrm{m} \mathrm{d}^{-1}$ (LB) (Fig 3a). Monthly averaged $\mathrm{SR}_{2}: \mathrm{SR}_{12}$ ratios were also computed, as a measure of how SR in the surface 0 to $2 \mathrm{~cm}$ sediment interval varied temporally compared to the overall 0 to $12 \mathrm{~cm}$ depth-integrated profile (Fig. $3 \mathrm{~b}$ ). The resulting ratios were compared to the ratio of 0.17 (e.g. 1:6), which represents the theoretical $\mathrm{SR}_{2}: \mathrm{SR}_{12}$ ratio calculated for a 6 -interval profile with a depth-constant $\mathrm{SR}$ rate. This comparison indicated that $\mathrm{SR}_{2}: \mathrm{SR}_{12}$ ratios were suppressed at UB from April to September and enhanced at $\mathrm{MB}$ throughout the sampling period. The ratio approximated 0.17 at LB from April through June, then increased to an August maximum followed by a decrease through October/November. Significant withinsite seasonal differences were evident for both $\mathrm{SR}_{2}$ and $\mathrm{SR}_{12}$ rates (Table 1), including peak $\mathrm{SR}_{12}$ rates during summer at $\mathrm{MB}$ and during both summer and fall at UB and LB. There were no significant seasonal differences in site-specific $\mathrm{SR}_{2}: \mathrm{SR}_{12}$ ratios.

\section{Ancillary data}

Pore water $\mathrm{SO}_{4}{ }^{2-}$ profiles at UB were nearly constant with depth and generally $<8 \mathrm{mM}$ $\mathrm{SO}_{4}{ }^{2-}$ throughout the sampling period, with minimum concentrations $\left(<3 \mathrm{mM} \mathrm{SO}_{4}{ }^{2-}\right)$ during summer (Fig. 4). At $\mathrm{MB}, \mathrm{SO}_{4}{ }^{2-}$ shifted from a near-linear decrease with depth during spring to early summer (March to June), to an exponential decrease during mid-summer through fall (July to November), and was often undetectable below 5 and $10 \mathrm{~cm}$ during summer and fall. This was coincident with temporal variations in dissolved $\Sigma \mathrm{H}_{2} \mathrm{~S}$, which increased linearly with depth from March through June and exhibited mid-depth maximum just above the depth of $\mathrm{SO}_{4}{ }^{2-}$ depletion from July to November, with a September maximum (>5 mM). At $\mathrm{LB}_{,} \mathrm{SO}_{4}{ }^{2-}(\sim 20 \mathrm{mM})$ 

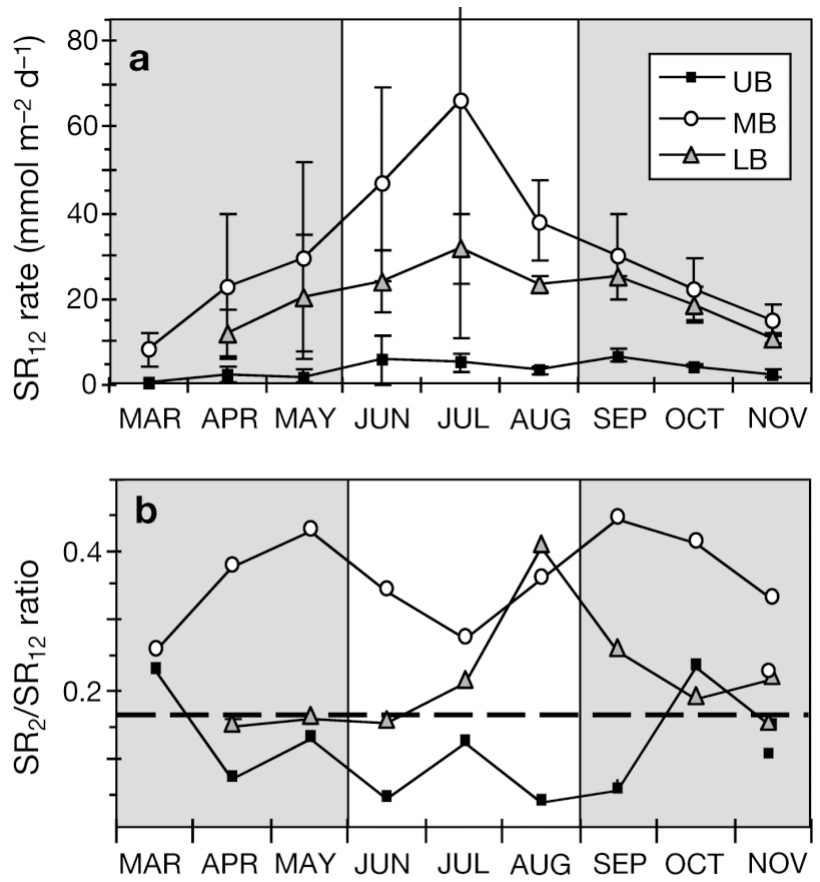

Fig. 3. (a) Depth-integrated 0 to $12 \mathrm{~cm}$ monthly average sulfate reduction rates $\left(\mathrm{SR}_{12}\right)$, and (b) ratio of the 0 to $2 \mathrm{~cm}$ interval rate to the integrated 0 to $12 \mathrm{~cm}$ rate $\left(\mathrm{SR}_{2}: \mathrm{SR}_{12}\right.$ ratio) for the 3 study sites (upper [UB], mid- [MB] and lower [LB] bay). Each point represents $n=1$ to 7 observations. Error bars represent either the absolute range (where $n=2$ ) or \pm 1 SD (where $n \geq 3$ ), and are omitted in (b) for clarity. The horizontal dashed line in (b) represents the theoretical 0.17 ratio that would be calculated for a vertically constant depth profile. Ratios above this line have enhanced $\mathrm{SR}_{2}$ rates, and those below the line have suppressed $\mathrm{SR}_{2}$ rates, in the surface 0 to $2 \mathrm{~cm}$ interval, relative to the total 0 to $12 \mathrm{~cm}$ integrated interval

exhibited no depletion with depth throughout the sampling period.

Examining the ratio of biogeochemically reactive $\mathrm{SO}_{4}{ }^{2-}$ to the more conservative $\mathrm{Cl}^{-}$anion provides a means for separating temporal variations in pore water $\mathrm{SO}_{4}{ }^{2-}$ concentration due to changing $\mathrm{SR}$ rates versus changes due to diffusion of overlying water $\mathrm{SO}_{4}{ }^{2-}$ into sediment resulting from variable freshwater flow. The molar $\mathrm{SO}_{4}{ }^{2-}: \mathrm{Cl}^{-}$ratio for full-strength seawater $(0.05 \%)$ is an order of magnitude lower than that of average river water $(0.53 \%$ ) (calculated from data given in Turekian 1968). The increase in this ratio, along a conservative mixing gradient going from full-strength seawater $(36 \%)$ to river water (assuming $0 \%$ ), is negligible above $2 \%$ salinity $\left(\mathrm{SO}_{4}{ }^{2-}: \mathrm{Cl}^{-}\right.$ratio $\left.=0.06\right)$. Below $2 \%$ the ratio increases gradually until $0.1 \%\left(\mathrm{SO}_{4}{ }^{2-}: \mathrm{Cl}^{-}\right.$ratio $\left.=0.11\right)$, at which point the ratio rapidly increases to 0.53 as salinity approaches $0 \%$. The high $\mathrm{SO}_{4}{ }^{2-}: \mathrm{Cl}^{-}$ratios $(>0.05)$ in UB surface sediment from April through August (Fig. 5) coincided with the period of decreasing salinity (Fig. 6c) and decreasing Susquehanna River flow (Fig. 6a). Be-
Table 1. Seasonal averages of 0 to $2 \mathrm{~cm}$ surface sediment and 0 to $12 \mathrm{~cm}$ depth-integrated sulfate reduction (SR) rates and ancillary parameters for the 1989 to 1994 Chesapeake Bay Land-Margin Ecosystem Research (LMER) program, from 3 sites (upper [UB], mid$[\mathrm{MB}]$ and lower [LB] bay) along the Chesapeake Bay central channel. SD given in parentheses. Significant differences $(p<0.05)$ among seasons (within-site) are indicated by different letters with ranking determined using Tukey's multi-comparison method. The number of observations is given as n. $E_{\mathrm{h}}$ : sediment redox; PC: particulate carbon; PN: particulate nitrogen

\begin{tabular}{|c|c|c|c|c|c|c|c|c|c|}
\hline \multirow{2}{*}{$\begin{array}{l}\text { Parameter/ } \\
\text { Season }\end{array}$} & \multicolumn{3}{|c|}{ / $=\mathrm{UB}-$} & \multicolumn{3}{|c|}{$-\mathrm{MB}=$} & \multicolumn{3}{|c|}{$-\mathrm{LB}-$} \\
\hline & Avg. & Rank & & Avg. & Rank & $\mathrm{n}$ & Avg. $\mathrm{F}$ & Rank & $\mathrm{n}$ \\
\hline \multicolumn{10}{|c|}{$\mathrm{SR} ; 0$ to $2 \mathrm{~cm}\left(\mathrm{mmol} \mathrm{m}^{-2} \mathrm{~d}^{-1}\right)$} \\
\hline Spring & $0.2(0.2)$ & B & 10 & $8.2(8.9)$ & A & 11 & $2.3(2.0)$ & B & 9 \\
\hline Summer & $0.5(0.4)$ & $\mathrm{AB}$ & 8 & $16.2(10.2)$ & A & 12 & $6.3(3.2)$ & $\mathrm{A}$ & 9 \\
\hline Fall & $0.7(0.4)$ & A & 7 & $8.6(4.1)$ & A & 8 & $3.8(1.6)$ & $\mathrm{AB}$ & 5 \\
\hline \multicolumn{10}{|c|}{$\mathrm{SR} ; 0$ to $12 \mathrm{~cm}\left(\mathrm{mmol} \mathrm{m}-2 \mathrm{~d}^{-1}\right)$} \\
\hline Spring & $2.0(1.6)$ & B & 10 & $21.4(18.0)$ & B & 11 & $14.9(9.9)$ & B & 9 \\
\hline Summer & $5.1(3.3)$ & A & 8 & $54.5(40.4)$ & A & 12 & $29.1(7.6)$ & A & 9 \\
\hline Fall & $4.0(1.7)$ & $\mathrm{AB}$ & 7 & $21.4(7.9)$ & B & 8 & $18.4(5.8)$ & $\mathrm{AB}$ & 5 \\
\hline \multicolumn{10}{|c|}{$\mathrm{SO}_{4}{ }^{2-}$ pool; 0 to $2 \mathrm{~cm}\left(\mathrm{mmol} \mathrm{m}^{-2}\right)$} \\
\hline Spring & $38(36)$ & B & 10 & $217(42)$ & A & 11 & $219(41)$ & A & 9 \\
\hline Summer & $34(25)$ & B & 9 & $141(43)$ & B & 12 & $246(37)$ & A & 9 \\
\hline Fall & $83(40)$ & A & 7 & $209(37)$ & A & 8 & $234(20)$ & A & 5 \\
\hline \multicolumn{10}{|c|}{$\mathrm{SO}_{4}{ }^{2-}$ pool; 0 to $12 \mathrm{~cm}\left(\mathrm{mmol} \mathrm{m}^{-2}\right)$} \\
\hline Spring 2 & 241 (149) & $\mathrm{AB}$ & 10 & $941(284)$ & A & 11 & $1165(144)$ & $\mathrm{A}$ & 9 \\
\hline Summer & $170(121)$ & B & 9 & $2(230)$ & B & 12 & $1346(220)$ & $\mathrm{A}$ & 9 \\
\hline Fall & 369 (132) & A & 7 & $505(173)$ & B & 8 & $1266(130)$ & $\mathrm{A}$ & 5 \\
\hline \multicolumn{10}{|c|}{$\sum \mathrm{H}_{2} \mathrm{~S}_{;}<2 \mathrm{~cm}\left(\mathrm{mmol} \mathrm{m}^{-2}\right)$} \\
\hline Spring & & & & $0.4(1.4)$ & B & 11 & & & \\
\hline Summer & & & & $17.8(17.9)$ & A & 12 & & & \\
\hline Fall & & & & $4.0(5.5)$ & B & 8 & & & \\
\hline \multicolumn{10}{|c|}{$\sum \mathrm{H}_{2} \mathrm{~S} ; 0$ to $12 \mathrm{~cm}\left(\mathrm{mmol} \mathrm{m}^{-2}\right)$} \\
\hline Spring & & & & $60(34)$ & B & 11 & & & \\
\hline Summer & & & & $233(110)$ & A & 12 & & & \\
\hline Fall & & & & $226(104)$ & A & 8 & & & \\
\hline \multicolumn{10}{|c|}{ Bottom water temperature $\left({ }^{\circ} \mathrm{C}\right)$} \\
\hline Spring 1 & $13.5(6.1)$ & $\mathrm{B}$ & 10 & $11.3(4.5)$ & $\mathrm{C}$ & 11 & $14.2(3.6)$ & B & 9 \\
\hline Summer & $25.1(3.4)$ & A & 9 & $23.5(2.8)$ & A & 12 & $23.3(3.4)$ & A & 9 \\
\hline Fall & $16.3(4.6)$ & $\mathrm{B}$ & 7 & $18.3(3.4)$ & $\mathrm{B}$ & 8 & $19.0(3.7)$ & $\mathrm{AB}$ & 5 \\
\hline \multicolumn{10}{|c|}{ PC:PN ratio } \\
\hline Spring 1 & $16.4(4.3)$ & A & 7 & $7.9(0.7)$ & A & 7 & $10.4(0.7)$ & B & 6 \\
\hline Summer & $17.6(5.1)$ & A & 8 & $7.6(0.7)$ & A & 10 & $11.0(0.7)$ & $\mathrm{AB}$ & 7 \\
\hline Fall & $14.8(2.9)$ & $\mathrm{A}$ & 6 & $7.5(0.5)$ & $\mathrm{A}$ & 8 & $11.3(1.1)$ & $\mathrm{A}$ & 4 \\
\hline \multicolumn{10}{|c|}{ Eh; 1 to $1.5 \mathrm{~cm}$ depth (mV) } \\
\hline Spring 1 & $121(138)$ & A & 9 & $-3(63)$ & $\mathrm{AB}$ & 9 & $145(106)$ & A & 9 \\
\hline Summer & 215 (123) & A & 9 & $-105(52)$ & B & 10 & $88(72)$ & A & 8 \\
\hline Fall & $203(108)$ & A & 6 & 74 (169) & A & 8 & $190(56)$ & A & 4 \\
\hline
\end{tabular}

cause UB often exhibited overlying water salinity $<2 \%$, surface sediment at this site was susceptible to $\mathrm{SO}_{4}{ }^{2-}: \mathrm{Cl}^{-}$ ratios $>0.05$, whereas MB and LB were not. Higher UB salinity in early spring (March) and fall resulted in a $\mathrm{SO}_{4}{ }^{2-}: \mathrm{Cl}^{-}$ratio $\sim 0.05$ in the uppermost sediment layer, with this ratio decreasing only at depths below $5 \mathrm{~cm}$. In contrast, a continuous decrease in the $\mathrm{SO}_{4}{ }^{2-}: \mathrm{Cl}^{-}$ratio with depth was evident at UB from April through August. Profiles of $\mathrm{SO}_{4}{ }^{2-}: \mathrm{Cl}^{-}$similarly decreased with depth at $\mathrm{MB}$ throughout the sampling period, but were essentially constant at 0.05 for LB. 


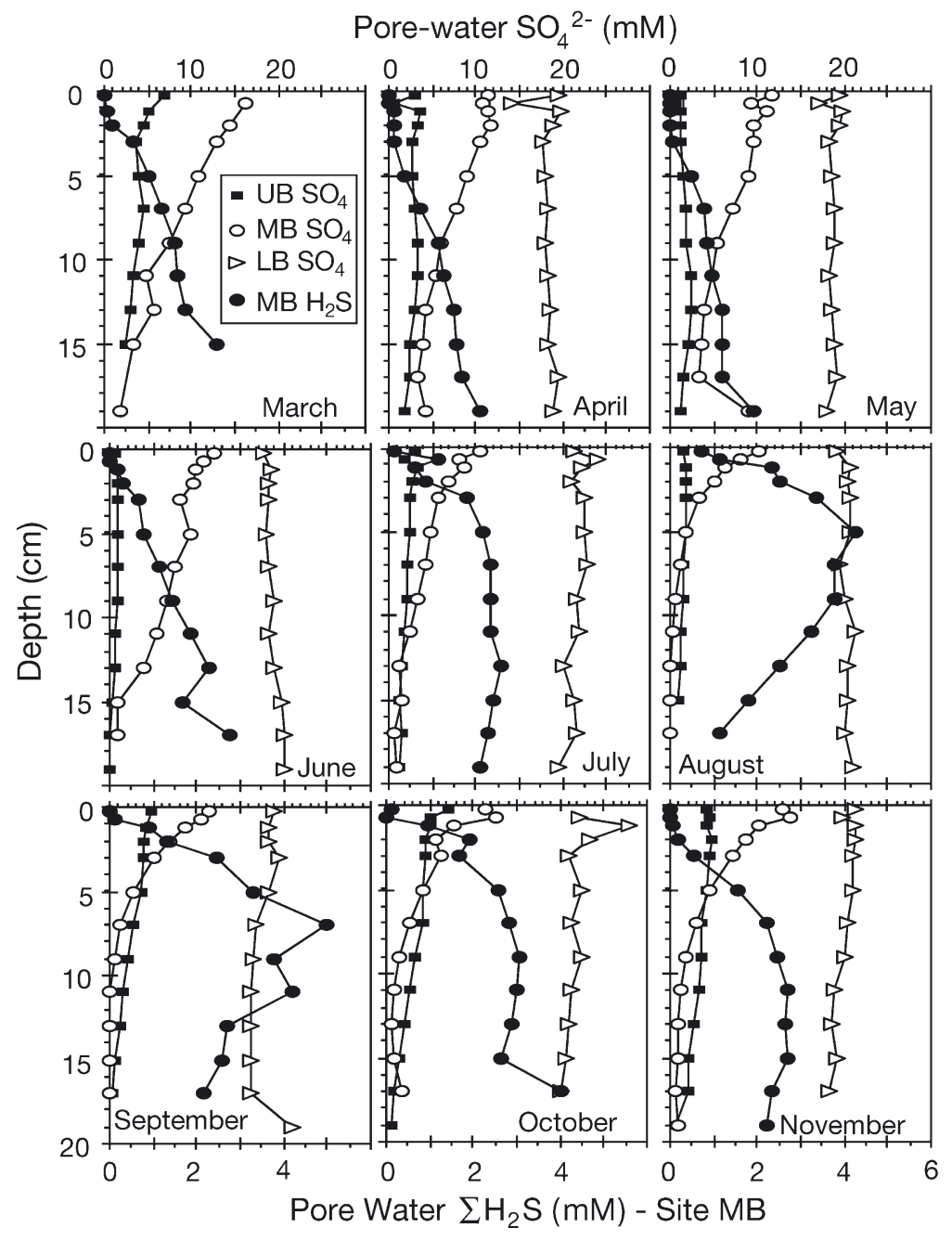

Fig. 4. Monthly averaged depth profiles of pore water sulfate and sulfide (MB only) for the 3 study sites (upper [UB], mid- [MB] and lower [LB] bay). Each data point represents $n=1$ to 7 date-specific observations

flected in sediment PC, PN, PC:PN, TOM or total reduced sulfur data, although consistent among-site differences were evident throughout the sampling period for all of these parameters (Fig. 6f,h-j,l). The decrease in $\mathrm{MB}$ pore water $\mathrm{SO}_{4}{ }^{2-}$ concentration during summer was significant, as was the corresponding decrease in sediment redox potential and increase in $\Sigma \mathrm{H}_{2} \mathrm{~S}$ (Fig. $6 \mathrm{~g}, \mathrm{k}, \mathrm{m}$, Table 1). Compared to overlying water concentrations, pore water $\mathrm{SO}_{4}{ }^{2-}$ was depleted in the top 0 to $2 \mathrm{~cm}$ at UB from May through July, and at MB from April through November, but was generally at or near watercolumn concentrations at LB throughout the year (data not shown).

\section{SR and temperature}

An Arrhenius-type model was applied to data grouped by season, site and integration depth to quantify the apparent temperature influence on SR. Significant seasonal model results are summarized in Table 2, and include: UB (0 to $12 \mathrm{~cm}$ data, fall only), MB (both integration depths, spring and fall only), and LB (all depth/season combinations, except the 0 to $2 \mathrm{~cm}$ data during spring). The fall data-grouping resulted in the best model fit $\left(\mathrm{r}^{2}>0.5\right)$ at all sites. No significant seasonal difference in $C_{\mathrm{t}}$ values was found for any of the 3 sites. When data were pooled into 2 temperature ranges $\left(<\right.$ or $\left.\geq 20^{\circ} \mathrm{C}\right)$, rates were statistically higher at $\geq 20^{\circ} \mathrm{C}$ at all 3 sites and both integration depths $\left(\mathrm{SR}_{2}\right.$ and $\left.\mathrm{SR}_{12}\right)$, except for $\mathrm{UB} \mathrm{SR}_{2}$ (data not shown). When the temperature model (Eq. 1) was applied to these 2

Since temporal changes in SR were most dynamic in the uppermost sediment layers, we focus much of our assessment on biogoechemical changes at the sediment-water interface. Fig. 6 depicts monthly averaged ancillary data for overlying bottom water (Fig. 6b-d) and the surface $0-1$ to $0-2 \mathrm{~cm}$ sediment horizon (depending on the constituent) (Fig. 6e-m). The predictable rise in temperature from spring through summer, and subsequent decrease during fall, was evident (Fig. 6b, Table 1) at all sites. Salinity increased from UB to LB, but was temporally less variable at MB and LB than at UB (Fig. 6c). Dissolved oxygen in overlying water decreased from April through August at all sites, with MB being the most depleted during summer (Fig. 6d). Both MB and LB sediments exhibited highest chl a concentrations during May (Fig. 6e). There were no significant (within-site) seasonal differences re- data groupings, a significant positive SR-temperature relationship was observed at $\mathrm{MB}$ for the $<20^{\circ} \mathrm{C}$ grouping, but not for the $\geq 20^{\circ} \mathrm{C}$ grouping (both integration depths). No significant SR-temperature relationships were found for either temperature grouping at UB or LB (at either integration depth). Only when the complete data set (all temperatures) was used for these latter 2 sites was a temperature relationship evident (i.e. Table 2, 'Year' grouping).

\section{SR and surface sediment parameters}

The relationship between $\mathrm{SR}_{2}$ rates and individual surface-sediment parameters $\left(\mathrm{SO}_{4}{ }^{2-}, \mathrm{chl} a, \mathrm{PC}, \mathrm{PN}\right.$, $\mathrm{PC}: \mathrm{PN}$, and TOM) were investigated with linearregression analysis (Table 3 ). Data were pooled by 
Table 2. Summary of $C_{\mathrm{t}}$ values (the temperature coefficient) calculated from Arrhenius-type model regressions of sulfate reduction (SR) and temperature data grouped by site and season, from 3 sites (upper [UB], mid [MB] and lower [LB] bay) along the Chesapeake Bay central channel. All regressions were significant at $p<0.05$, except those with the $r^{2}$-value designated with an asterisk, where $0.10>p>0.05$. Nonsignificant ( $p>0.1$ ) regressions are designated (ns). Seasons were omitted when neither integration depth yielded a significant regression. $C_{\mathrm{t}}$ (units: $\mathrm{kJ} \mathrm{mol}^{-1}$ ) calculated from the slopes of regressions of $\ln (\mathrm{SR})$ versus temperature ${ }^{-1} ; C_{\mathrm{t}}$ SEs are given in parentheses

\begin{tabular}{|llrcccc|}
\hline \multirow{2}{*}{ Site } & Season & $\mathrm{n}$ & \multicolumn{2}{c}{0 to $2 \mathrm{~cm}$} & \multicolumn{2}{c|}{0 to $12 \mathrm{~cm}$} \\
& & & $\mathrm{r}^{2}$ & $C_{\mathrm{t}}$ & $\mathrm{r}^{2}$ & $C_{\mathrm{t}}$ \\
\hline UB & Fall & 7 & $\mathrm{~ns}$ & & 0.81 & $57(12)$ \\
& Year & 25 & 0.19 & $53(25)$ & 0.39 & $51(13)$ \\
MB & Spring & 11 & 0.39 & $96(39)$ & $0.34^{*}$ & $73(34)$ \\
& Fall & 8 & 0.67 & $84(24)$ & 0.58 & $60(21)$ \\
& Year & 31 & 0.45 & $62(13)$ & 0.48 & $60(11)$ \\
LB & Spring & 9 & $\mathrm{~ns}$ & & $0.39^{*}$ & $69(33)$ \\
& Summer & 9 & $0.42^{*}$ & $70(31)$ & 0.49 & $38(15)$ \\
& Fall & 5 & 0.87 & $72(16)$ & 0.89 & $62(13)$ \\
& Year & 23 & 0.58 & $90(17)$ & 0.68 & $59(9)$ \\
& & & & & & \\
\hline
\end{tabular}

either site/season or site alone (i.e. 'Year' designation). At $\mathrm{UB}, \mathrm{SR}_{2}$ increased with $\mathrm{SO}_{4}{ }^{2-}$ concentration for the Year grouping only, although this relationship was weak $\left(\mathrm{r}^{2}=0.24\right)$. At $\mathrm{MB}, \mathrm{SR}_{2}$ increased with TOM and chl a during spring, and with PN for the Year grouping. At LB, $\mathrm{SR}_{2}$ increased with chl a during spring. Correlation analysis of temperature and the above sediment parameters indicated that of the significant relationships in Table 3, only LB/chl a/spring was correlated with both $\mathrm{SR}_{2}$ and temperature. Results for seasonally significant multiple-regression models are given in Table 4. At UB, combined temperature and $\mathrm{SO}_{4}{ }^{2-}$ explained approximately $50 \%$ of the variability in $\mathrm{SR}_{2}$ for the Year interval only. At MB, combined temperature and organic matter quantity (PC and $\mathrm{PN}$ ) explained $>75 \%$ of the variability in $\mathrm{SR}_{2}$ during both spring and fall. No LB multiple regressions were significant.

\section{Contribution of sulfate diffusion in supporting mesohaline sulfate reduction}

Molecular diffusion of $\mathrm{SO}_{4}{ }^{2-}$ in sediment is controlled by porosity, temperature, and the $\mathrm{SO}_{4}{ }^{2-}$ gradient (Eq. 2). Of these, the latter 2 factors had the greatest temporal influence on diffusion, and subsequently on the supply of new $\mathrm{SO}_{4}{ }^{2-}$ for benthic SR at site MB. While temperature increased through spring (Fig. 6b), $\mathrm{SO}_{4}{ }^{2-}$ gradients varied little (Fig. 4), and the resulting $\mathrm{SO}_{4}{ }^{2-}$ diffusion rate remained nearly constant and low through May ( 2 mmol $\left.\mathrm{m}^{-2} \mathrm{~d}^{-1}\right)$, and increased only modestly (to $\sim 4 \mathrm{mmol} \mathrm{m}^{-2} \mathrm{~d}^{-1}$ ) through July (Fig. 7).
Table 3. Values of $r^{2}$ from significant $(p<0.05)$ linear regressions of sulfate reduction rate $(0$ to $2 \mathrm{~cm})$ against individual surficial sediment parameters $[X]$, for data grouped by site/season or site/year (all site-specific data, irrespective of season), from 3 sites (upper [UB], mid- $[\mathrm{MB}]$ and lower [LB] bay) along the Chesapeake Bay central channel. Nonsignificant regressions are indicated (ns) and the number of observations is given in parentheses. PN: particulate nitrogen; TOM: total organic matter

\begin{tabular}{|lccc|}
\hline Site & $X$ & Spring & Year \\
\hline UB & $\mathrm{SO}_{4}{ }^{2-}$ & $\mathrm{ns}$ & $0.24(25)$ \\
MB & $\mathrm{PN}$ & $\mathrm{ns}$ & $0.18(24)$ \\
MB & $\mathrm{TOM}$ & $0.64(7)$ & $\mathrm{ns}$ \\
MB & $\mathrm{Chl} a$ & $0.95(5)$ & $\mathrm{ns}$ \\
LB & $\mathrm{Chl} a$ & $0.89(5)$ & $\mathrm{ns}$ \\
\hline
\end{tabular}

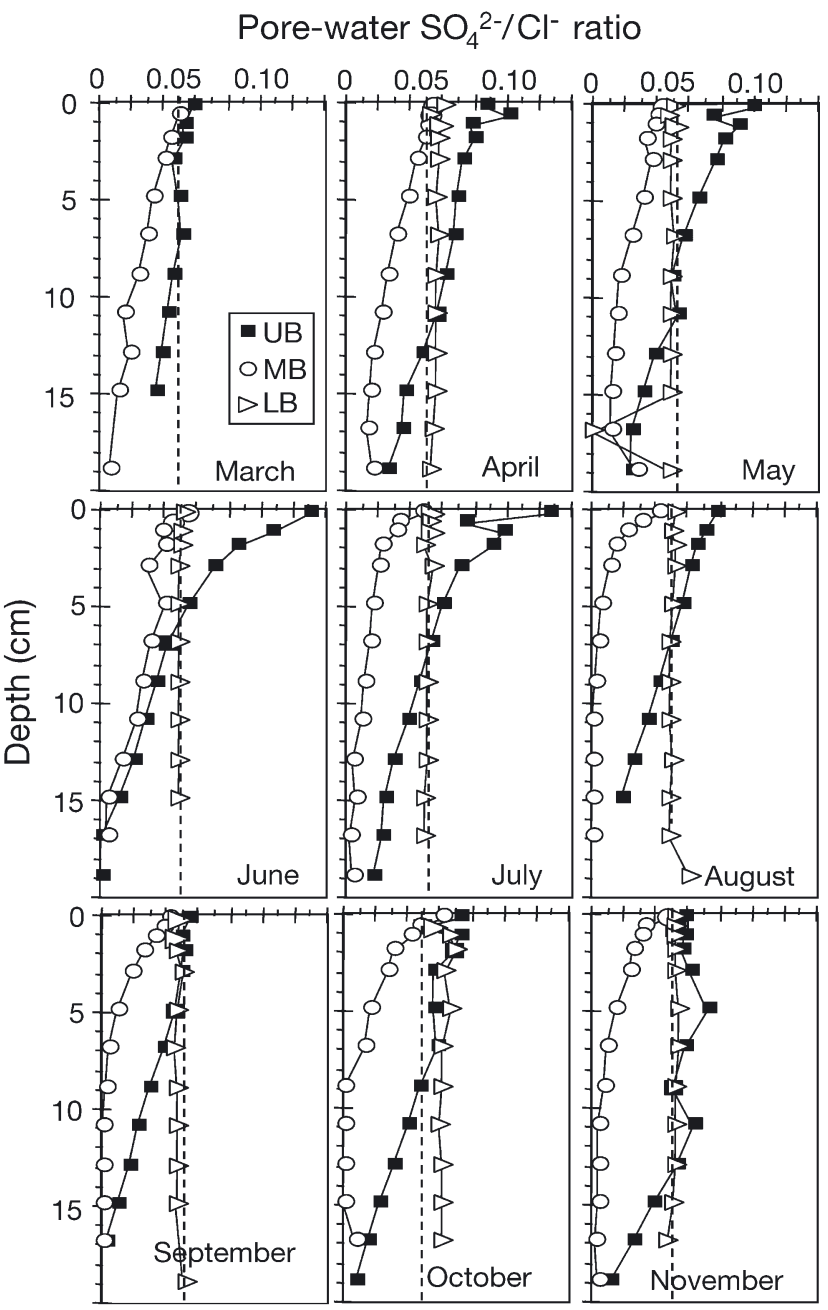

Fig. 5. Monthly averaged depth profiles of pore water sulfate: chloride $\left(\mathrm{SO}_{4}{ }^{2-}: \mathrm{Cl}^{-}\right)$ratio for the 3 study sites (upper [UB], mid- [MB] and lower [LB] bay). Each data point represents the average of $n=1$ to 7 date-specific observations. The horizontal dashed line represents the theoretical 0.05 ratio at $\geq 2 \%$ o salinity, calculated by a conservative mixing model (see 'Results; Ancillary data') 

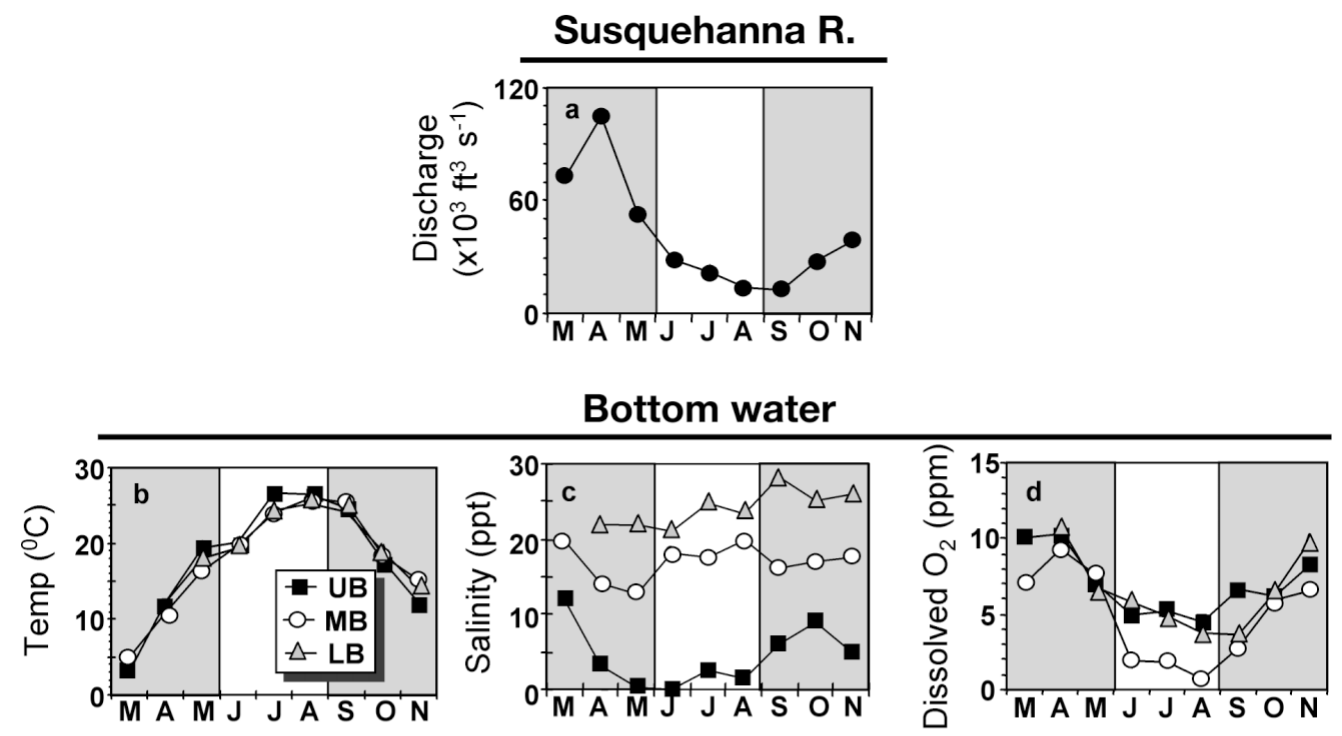

Surface sediment
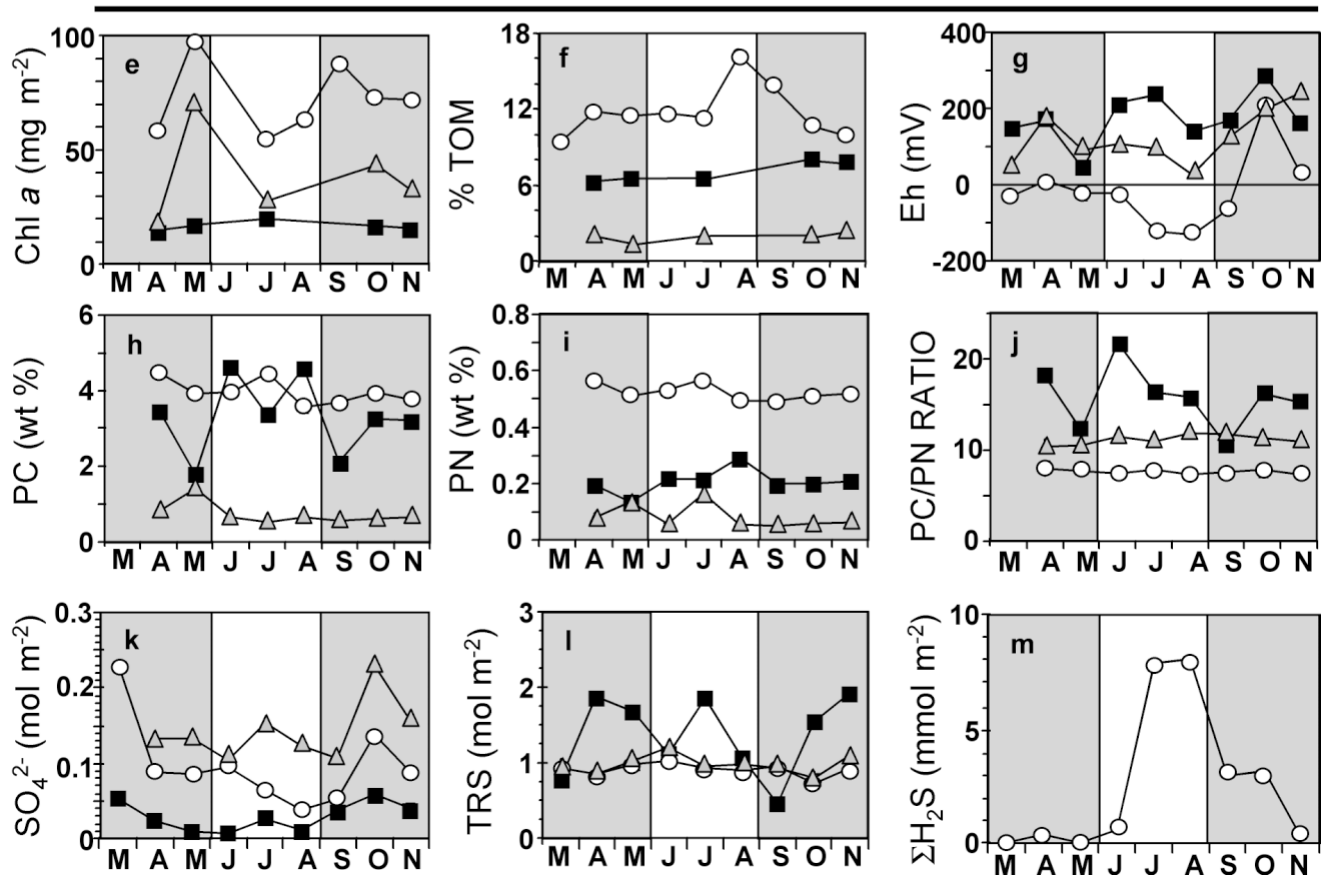

Fig. 6. Monthly averaged ancillary parameter data for (a) the Susquehanna River, (b-d) water overlying benthic sample site, and $(\mathrm{e}-\mathrm{m})$ surface sediment. The specific depth interval for each sediment parameter is as follows: 0 to $1 \mathrm{~cm}$ (chl $a$, particulate carbon $[\mathrm{PC}]$, particulate nitrogen [PN], PC:PN, total organic matter [TOM], sediment redox $\left.\left[E_{\mathrm{h}}\right]\right), 0$ to $2 \mathrm{~cm}$ (total reduced sulfur [TRS], $\left.\mathrm{SO}_{4}{ }^{2-}, \Sigma \mathrm{H}_{2} \mathrm{~S}\right]$ ). The Susquehanna River flow data represents discharge at Conowingo Dam (USGS 1987-1994). Each data point represents the average of $n=1$ to 7 individual date measurements

However, as $\mathrm{SR}_{12}$ increased more than 8-fold from 8 to $67 \mathrm{mmol} \mathrm{m}^{-2} \mathrm{~d}^{-1}$ during the March through July period (Fig. 3a), the fraction of the $\mathrm{SO}_{4}{ }^{2-}$ demand supplied by diffusion necessarily decreased from 33\% in March to $<10 \%$ in the May through July period. The fraction of $\mathrm{SR}_{12}$ supported by $\mathrm{SO}_{4}{ }^{2-}$ diffusion increased sharply to $>30 \%$ in August due to a decreased $\mathrm{SR}_{12}$ and to a sharp increase in $\mathrm{SO}_{4}{ }^{2-}$ diffusion, driven by peak temperatures and a steep $\mathrm{SO}_{4}{ }^{2-}$ gradient. With decreasing temperatures and $\mathrm{SR}_{12}$ rates in the fall, the corresponding fraction of $\mathrm{SO}_{4}{ }^{2-}$ supplied by diffusion rose to a maximum of $50 \%$ by November. A similar quantitative assessment of $\mathrm{SO}_{4}{ }^{2-}$ diffusion at UB and LB was not practical because monthly $\mathrm{SO}_{4}{ }^{2-}$ gradients were either 
Table 4. Significant $(p<0.05)$ results for multiple-regression models (Eq. 5), where $T$ is temperature, $X$ is a single surface sediment variable, and $\mathrm{N}$ is the number of observations. Data, from 3 sites (upper [UB], mid- [MB] and lower [LB] bay) along the Chesapeake Bay central channel, were pooled by site-season. The site-year grouping indicates all data were used, irrespective of season. The level of significance for individual regression coefficients $(\mathrm{a}$ and $\mathrm{b})$ are indicated by ${ }^{*} \mathrm{p}<0.1,{ }^{* *} \mathrm{p}<0.05$, or ${ }^{* * *} \mathrm{p}<0.005$, respectively. PC: particulate carbon; PN: particulate nitrogen

\begin{tabular}{|c|c|c|c|c|c|}
\hline Site & Season & Model $r^{2}$ & $\mathrm{~N}$ & $T$ & $X$ \\
\hline \multicolumn{6}{|c|}{ Model: $\mathrm{SR}_{2}=\mathrm{a}[T]+\mathrm{b}\left[\mathrm{SO}_{4}\right]+\mathrm{c}$} \\
\hline UB & Year & 0.49 & 25 & ${ }^{* * *}$ & **** \\
\hline \multicolumn{6}{|c|}{ Model: $\mathrm{SR}_{2}=\mathrm{a}[T]+\mathrm{b}[\mathrm{PC}]+\mathrm{c}$} \\
\hline MB & Spring & 0.78 & 7 & ${ }^{*}$ & * \\
\hline MB & Fall & 0.82 & 7 & ${ }^{* *}$ & * \\
\hline MB & Year & 0.29 & 24 & ${ }^{* *}$ & * \\
\hline \multicolumn{6}{|c|}{ Model: $\mathrm{SR}_{2}=\mathrm{a}[T]+\mathrm{b}[\mathrm{PN}]+\mathrm{c}$} \\
\hline MB & Spring & 0.80 & 7 & ${ }^{*}$ & *** \\
\hline MB & Fall & 0.92 & 7 & ${ }^{* *}$ & *** \\
\hline MB & Year & 0.37 & 24 & ${ }^{* *}$ & *** \\
\hline
\end{tabular}

minor or zero (Fig. 4), largely due to bioturbation, and thus diffusion calculations were not reliable.

\section{Interannual variation in summertime sulfate reduction rates}

For the years 1987 to 1994, spring peak flow from the Susquehanna River occurred as early as February and as late as May (Fig. 8). The magnitude of this peak was highest in April 1993, followed by April 1994, and lowest in April 1992. Significant relationships between spring river flow and July $\mathrm{SR}_{2}$ rates were observed at all 3 sites (Fig. 9), although the time window for river flow-averaged data that resulted in the best regression fit varied among sites. The strongest relationship at Site UB was found using April river flow. However, this regression was heavily weighted by the 1993 data,

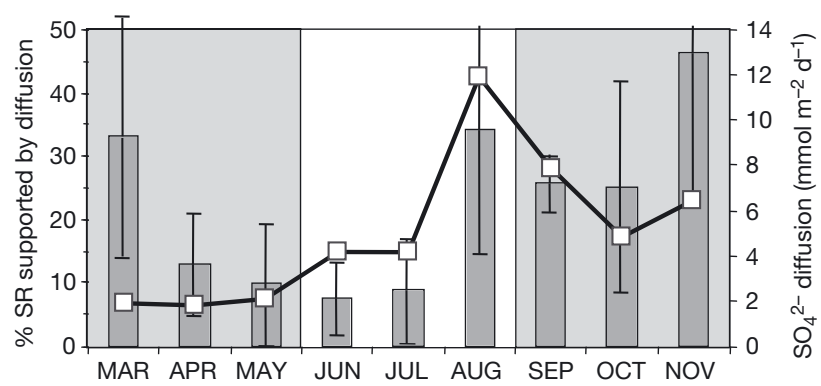

Fig. 7. Monthly averaged sulfate diffusion rates into the midbay Site MB sediment (line with white squares) and the percentage of 0 to $12 \mathrm{~cm}$ depth-integrated sulfate reduction rate supported by this amount of sulfate diffusion (bars)

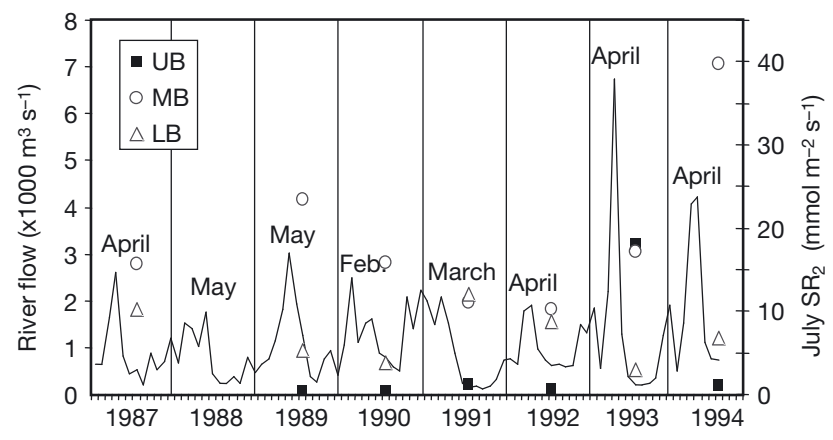

Fig. 8. Continuous monthly average Susquehanna River flow data (USGS 1987-1994) from January 1987 to July 1994, with the month of highest flow indicated for each year. The annual July 0 to $12 \mathrm{~cm}$ integrated sulfate reduction rate for each site is shown as symbols. Previously published 0 to $12 \mathrm{~cm}$ monthly average sulfate reduction rate $\left(\mathrm{SR}_{12}\right)$ data (Roden \& Tuttle 1993a) is included from July 1987 for sites R64 and LB3, located $<1 \mathrm{~km}$ from sites MB and LB, respectively

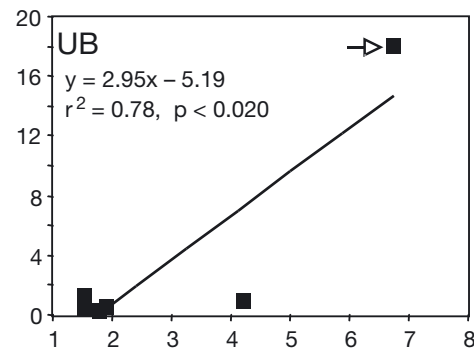

April River Flow (x1000 m $\left.\mathrm{s}^{-1}\right)$

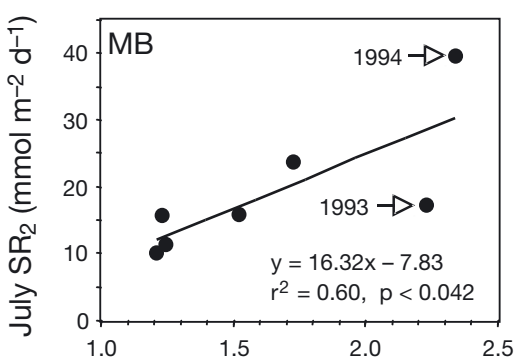

February-June River Flow (x1000 $\left.\mathrm{m}^{3} \mathrm{~s}^{-1}\right)$

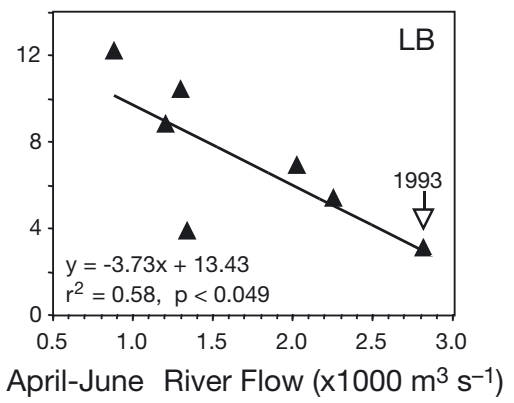

Fig. 9. Site-specific linear regressions of monthly averaged Susquehanna River flow data versus July 0 to $2 \mathrm{~cm}$ sulfate reduction rate for the 3 study sites (upper [UB], mid- [MB] and lower [LB] bay). The time window for river flow was varied in each case until the best fit to the data was obtained 
which had a July $\mathrm{SR}_{2}$ rate $\left(18.0 \pm 4.3 \mathrm{mmol} \mathrm{m} \mathrm{m}^{-2} \mathrm{~d}^{-1}\right.$, $\mathrm{n}=2$ ) more than $12 \times$ that of any other value measured for this site. This enhanced rate appeared to be due to the rapid input of utilizable carbon during the intense spring 1993 freshet, rather than to increased $\mathrm{SO}_{4}{ }^{2-}$, as July $1993 \mathrm{SO}_{4}{ }^{2-}$ concentration throughout the top $12 \mathrm{~cm}$ of sediment (1.4 to $2.4 \mathrm{mM}$ ) was comparable to values observed during July for the other $5 \mathrm{yr}$ of sampling (Fig. 4). None of the UB regressions were significant when the 1993 data was omitted. A significant positive relationship between July $\mathrm{SR}_{2}$ at $\mathrm{MB}$ and river flow was observed only when a wide-averaged time window (February to June) was used. In contrast, a strong negative relationship between April and June time-averaged river flow and $\mathrm{SR}_{2}$ was evident for $\mathrm{LB}$. Regressing the annual peak river-flow rates (letting the specific month vary) against July $\mathrm{SR}_{2}$ did not improve regression fits at any site.

\section{DISCUSSION}

The 6 yr LMER time series allows for examination of the factors controlling microbial SR in estuarine sediments on monthly, seasonal and interannual timescales. Qualitative trends and interactions are evident at all 3 scales, while statistically significant quantitative trends are most apparent seasonally, and to a lesser extent interannually.

\section{Temperature}

Temperature exerts an ever-present control on microbial metabolic rates. While individual bacterial strains have discrete temperature optima, a continuous increase in whole-sediment community SR rates throughout the environmental range of temperatures can be reasonably expected. However, seasonal patterns of site-specific SR rates and temperature did not always parallel each other (Table 1). While the SR-temperature relationship was significant for most seasons/site/depth combinations (Table 2), the exceptions point to conditions when SR was substantially influenced by other factors. The lack of a significant SR-temperature relationship during spring and summer at UB (both depths) was primarily linked to the decreasing pool of overlying water $\mathrm{SO}_{4}{ }^{2-}$ (i.e. $\mathrm{SO}_{4}{ }^{2-}$ limitation) associated with increased river flow during this high-flow period.

Sulfate limitation does not explain the lack of a significant SR-temperature relationship during spring at LB ( 0 to $2 \mathrm{~cm}$ interval), as evidenced by the persistently high $\mathrm{SO}_{4}{ }^{2-}$ concentration at this site. Since SR at Site LB is C-limited overall (Marvin-DiPasquale \& Capone 1998), it is presumably most limited just prior to deposition of the bulk of the annual spring phytoplankton bloom in late May to early June (Malone et al. 1988). Further, an increase in macrofauna bioturbation rates with increasing spring temperature can stimulate both microbial SR (Hines \& Lyons 1982) and other heterotrophic microbes (e.g. aerobes, denitrifiers, Fe- and Mn-reducers) by replenishing suitable electron acceptors (e.g. $\mathrm{O}_{2}, \mathrm{NO}_{3}{ }^{-}, \mathrm{Fe}[\mathrm{III}], \mathrm{Mn}[\mathrm{IV}]$ (Aller \& Aller 1998). Thus, during the period of peak C-limitation, other bacterial groups may effectively compete with SRB for organic substrates, which would suppress the SR maximum rate in near-surface sediments and mask the spring SR-temperature relationship at LB. This competition for organic substrate may be relieved after the spring-bloom material has been deposited and mixed into the sediment, and the pool size of electron acceptors more favorable than $\mathrm{SO}_{4}{ }^{2-}$ has declined. In contrast to both UB and LB, the spring $\mathrm{SR}_{2}$-temperature relationship was significant at $\mathrm{MB}$, where neither $\mathrm{SO}_{4}{ }^{2-}$ nor $\mathrm{C}$ were limiting, and bioturbation was minimal to absent (Kemp et al. 2000, USACE 2000).

The lack of a significant SR-temperature correlation at $\mathrm{MB}$ (both depths) during summer, and for the $\geq 20^{\circ} \mathrm{C}$ data grouping, suggests that factors other than temperature limit SR at this site and season (or temperature range). For $\mathrm{SR}_{12}$ this clearly reflects $\mathrm{SO}_{4}{ }^{2-}$ limitation at depth during mid- to late summer (Fig. 4). A similar explanation for $\mathrm{SR}_{2}$ would seem unlikely because $\mathrm{SO}_{4}{ }^{2-}$ concentration in the 0 to $2 \mathrm{~cm}$ surface sediment remained consistently high ( $>5 \mathrm{mM}$ ) throughout the year. Thus, short of temperature or sulfate limitation, it would appear that the availability of specific organic substrates (e.g. acetate, lactate, etc.) limits SR in the 0 to $2 \mathrm{~cm}$ interval at $\mathrm{MB}$ during summer. Even though there is a supply of recently deposited fresh organic matter in the mesohaline surface sediment, in the form of senescent spring diatoms, the supply of suitable low molecular weight organic substrates for SRB may ultimately be limited by the activity of fermenting bacteria that generate these substrates from high molecular weight organic precursors (Ahmed et al. 1992). The lack of a significant SR-temperature relationship for the $\geq 20^{\circ} \mathrm{C}$ data grouping was similar to the lack of correlation between temperatures $>20^{\circ} \mathrm{C}$ and heterotrophic bacterioplankton abundance, production or specific growth rate reported for mesohaline Chesapeake Bay waters (Shiah \& Ducklow 1994). In that study it was concluded that organic substrate supply limits bacterioplankton production and abundance during summer only, and that temperature limits these parameters during all non-summer periods.

Temperature may have been the strongest controlling influence on SR rates during fall, as this season consistently exhibited the best model fit $\left(r^{2} \geq 0.5\right)$ at all 
sites (Table 2). By fall, much of the diatom bloom that was rapidly deposited during spring has been degraded (Malone et al. 1988, Zimmerman \& Canuel 2001). Further, the phytoplankton biomass reaching the sediment during both summer and fall has decreased, relative to spring, due to nutrient limitation and a shift from larger diatom cells to picoplankton (Smith \& Kemp 1995, 2001). Thus, the apparent SR-temperature relationship during fall is not subject to as much perturbation due to rapidly changing organic loading conditions, as is the case during the spring-summer transition.

A major assumption underlying the Arrhenius relationship is that $E_{\mathrm{a}}$ is constant over the temperature range of reactions. Previous work with salt marsh sediments demonstrated that neither the $E_{\mathrm{a}}$ nor the temperature optima for in situ SRB varied seasonally (Abdollahi \& Nedwell 1979). In that study, true $E_{\mathrm{a}}$ values were calculated each season from simultaneous incubations at multiple temperatures. In contrast, seasonal differences may be observed for apparent $E_{\text {a }}$ (i.e. $C_{\mathrm{t}}$ ) values calculated from seasonal SR data generated from incubations conducted on different dates at in situ temperatures. Apparent $E_{\mathrm{a}}$ values ranged from $21 \mathrm{~kJ}$ $\mathrm{mol}^{-1}$ in winter to $117 \mathrm{~kJ} \mathrm{~mol}^{-1}$ in summer for Cape Lookout Bight marine sediments (Crill \& Martens 1987). Seasonal differences were attributed to changes in reaction mechanisms, with winter rates being further from steady state. The lack of winter samples in the current study did not allow for the same wintersummer comparisons, and the error associated with the $C_{\mathrm{t}}$ values was sufficiently large to mask any significant seasonal differences within each site (Table 2). However, these studies illustrate the importance of differentiating between true versus apparent $E_{\mathrm{a}}$ calculations. Only by experimentally varying temperature alone can the temperature influence on microbial rates be explicitly ascertained. Apparent $E_{\mathrm{a}}\left(C_{\mathrm{t}}\right)$ calculations, as conducted in the current study and Cape Lookout Bight study, may be influenced by temporal variations in other factors, such as electron donor and acceptor availability.

\section{Sulfate concentration}

Sulfate is the electron acceptor for SR, and thus may limit this microbial process at low concentrations (Capone \& Kiene 1988). The supply of $\mathrm{SO}_{4}{ }^{2-}$ from the overlying water to the sediment varies with salinity (cf. Fig. 6k and c) on timescales from hours (tidal cycles) to months (seasonal variations in river flow). The diffusive flux of $\mathrm{SO}_{4}{ }^{2-}$ may be either into or out of the sediment, depending on relative concentrations in the overlying water. Diffusion may be particularly important in the oligohaline region of the Bay, which has comparatively low $\mathrm{SO}_{4}{ }^{2-}$ and is the region most strongly impacted by seasonal changes in Susquehanna River freshwater flow. Overlying water and surface sediment $(0$ to $1 \mathrm{~cm}) \mathrm{SO}_{4}{ }^{2-}$ concentrations were generally at or near equilibrium at UB, and ranged from 0.6 to $9 \mathrm{mM}$. This was both above and below the 1 to $3 \mathrm{mM}$ range considered limiting for SR in marine sediments (Boudreau \& Westrich 1984, Skyring 1987). However, half-saturating substrate concentrations $\left(K_{\mathrm{s}}\right.$ values) as low as $0.03 \mathrm{mM} \mathrm{SO}_{4}{ }^{2-}$ have been shown for SR in low-salinity estuarine environments (Roden \& Tuttle 1993b). On short timescales, the degree of $\mathrm{SO}_{4}{ }^{2-}$ limitation thus depends on the overall $K_{\mathrm{s}}$ of the particular SR community. On longer timescales (months to seasons), the rate at which the community composition can shift between populations having higher or lower $\mathrm{SO}_{4}{ }^{2-}$ affinities may dictate the degree and duration of $\mathrm{SO}_{4}{ }^{2-}$ limitation. The extent to which apparent (community-integrated) $K_{\mathrm{s}}$ values may vary in response to changing $\mathrm{SO}_{4}{ }^{2-}$ levels has not been adequately addressed in transitional coastal systems.

The positive relationship between $\mathrm{SR}_{2}$ and $\mathrm{SO}_{4}{ }^{2-}$ at UB (Table 3), as well as the fact that $\mathrm{SO}_{4}{ }^{2-}$ and temperature combined could account for approximately $50 \%$ of the variability in $\mathrm{SR}_{2}$ (Table 4 ), demonstrates that $\mathrm{SR}_{2}$ was at least partially controlled by $\mathrm{SO}_{4}{ }^{2-}$ in the UB region. However, since in both cases these $\mathrm{SR}_{2}-\mathrm{SO}_{4}{ }^{2-}$ relationships were significant for the Year grouping only, and not for any specific season, the periodicity of these relationships appears to be out of phase with our seasonal delineation. Alternatively, the relationships are sufficiently subtle as to not be detectable with the limited number of seasonally specific observations. Assessing $\mathrm{SO}_{4}{ }^{2-}$ limitation at UB in deeper sediment by considering $\mathrm{SO}_{4}{ }^{2-}$ depth profiles (Fig. 4) is difficult because concentrations are low to begin with, and generally decrease only gradually with depth. It is therefore helpful to consider the molar $\mathrm{SO}_{4}{ }^{2-}: \mathrm{Cl}^{-}$ratio (Fig. 5). This allows biologically and chemically mediated changes in pore water $\mathrm{SO}_{4}{ }^{2-}$ concentration to be separated from physical processes of molecular diffusion and advection (Jørgensen 1977). Assuming no significant biological or abiotic chemical removal or production, pore water $\mathrm{Cl}^{-}$concentration is controlled by diffusion and advection, and profile gradients reflect the magnitude and direction of $\mathrm{Cl}^{-}$flux (Matisoff 1980). Both increasing and decreasing linear $\mathrm{Cl}^{-}$gradients were observed for UB and $\mathrm{MB}$, while LB profiles were generally vertically constant (data not shown). The decrease in $\mathrm{SO}_{4}{ }^{2-}: \mathrm{Cl}^{-}$ ratios with depth at $\mathrm{UB}$ and $\mathrm{MB}$ thus reflects $\mathrm{SO}_{4}{ }^{2-}$ depletion via SR. In our earlier report (MarvinDiPasquale \& Capone 1998), we argued that SR in the top $12 \mathrm{~cm}$ of sediment is primarily controlled by C- 
limitation in the oligohaline region of the Bay. However, the $\mathrm{SO}_{4}{ }^{2-}: \mathrm{Cl}^{-}$profiles presented here indicate that $\mathrm{SO}_{4}{ }^{2-}$ is being depleted relative to $\mathrm{Cl}^{-}$most dramatically from April through August, and at depths below $5 \mathrm{~cm}$ during early spring and fall. Thus, $\mathrm{SO}_{4}{ }^{2-}$ limitation also appears to be an important factor at UB and $\mathrm{MB}$, particularly in deeper sediments $(>12 \mathrm{~cm})$. The constant $\mathrm{SO}_{4}{ }^{2-}: \mathrm{Cl}^{-}$ratio at $\mathrm{LB}$, at or near the conservative mixing ratio, confirms our earlier findings that this site was $\mathrm{C}$ - and not $\mathrm{SO}_{4}{ }^{2-}$-limited.

The observation that $\mathrm{SO}_{4}{ }^{2-}$ diffusion accounted for $<10 \%$ of the $\mathrm{SO}_{4}{ }^{2-}$ demand at $\mathrm{MB}$ during the springsummer transition (May to July), and a larger proportion (30 to $50 \%$ ) during early spring and late fall (Fig. 7), was similar to an earlier report in which depth-integrated benthic SR exceeded modeled diffusive influx of $\mathrm{SO}_{4}{ }^{2-}$ (Urban et al. 1994). The balance of the $\mathrm{SO}_{4}{ }^{2-}$ needed to fuel SR can only be supplied by advective transport and/or by S-recycling. Bioturbation may facilitate the transport of both $\mathrm{SO}_{4}{ }^{2-}$ and $\mathrm{O}_{2}$ into sediment, the latter of which may further reoxidize reduced-S compounds back to $\mathrm{SO}_{4}{ }^{2-}$ (Berner \& Westrich 1985). However, the absence of benthic macrofauna at Site MB during the warm months suggests that bioturbation is not significant in this case, and that any S-recycling must occur by other pathways. Potential microbial pathways include the disproportionation of thiosulfate to $\mathrm{SO}_{4}{ }^{2-}$ and sulfide (Jørgensen 1990a,b) and anaerobic elemental $\mathrm{S}^{0}$ oxidation via $\mathrm{Fe}(\mathrm{III})$ and/or $\mathrm{Mn}(\mathrm{IV})$ reduction (Thamdrup et al. 1993, Lovley \& Phillips 1994). By difference, such reoxidation processes accounted for roughly 50 (late fall) to $90 \%$ (April to July) of the $\mathrm{SO}_{4}{ }^{2-}$ demand. A direct analysis of the temporal dynamics of the above constituents would be necessary to validate this conclusion. However, the possibility that $\mathrm{SR}_{12}$ rates are overestimated due to inadvertent $\mathrm{SO}_{4}{ }^{2-}$ stimulation of SRB is not likely, as carrier-free ${ }^{35} \mathrm{SO}_{4}{ }^{2-}$ amendments (i.e. no nonradioactive $\mathrm{SO}_{4}{ }^{2-}$ ) were used in all 'true tracer' whole-core SR rate assays (final pore water ${ }^{35} \mathrm{SO}_{4}{ }^{2-}$ amendment concentration per interval $\approx 0.1 \mathrm{nM}$ ). Another possibility is that the calculated $\mathrm{SO}_{4}{ }^{2-}$ diffusion rates are underestimated, which could result if the sediment porosity $(\phi)$, the whole sediment temperature-dependent diffusion coefficient $\left(D_{\mathrm{s}(T)}\right)$, or change in $\mathrm{SO}_{4}{ }^{2-}$ concentration with depth measurement $(\delta \mathrm{C} / \delta x)$ were underestimated in Eq. (2). Values of both $\phi$ and $\delta C / \delta x$ were measured directly and thus well established. Therefore, if any of the parameters in Eq. (2) were underestimated it is most likely $D_{\mathrm{s}(T)}$, which was calculated from Eq. (3) based on 1 previous assessment of $D_{\mathrm{s}(25)}$ at a nearby mesohaline site (Roden \& Tuttle 1992). However, even if the actual diffusion coefficient value at Site $\mathrm{MB}$ (at $25^{\circ} \mathrm{C}$ ) is
$50 \%$ greater than the measurement by Roden \& Tuttle $\left(1992\right.$; i.e. assume $\left.0.65 \mathrm{~cm}^{2} \mathrm{~d}^{-1}\right)$, then the estimate of how much total SR is directly supported by $\mathrm{SO}_{4}{ }^{2-}$ diffusion for the May to July low period would only increase from an average of 8.6 to $13.0 \%$. Thus, our conclusion would remain unchanged regarding this period, as being a particularly important time for Srecycling supporting $\mathrm{SR}$. While a similar assessment of $\mathrm{SO}_{4}{ }^{2-}$ diffusion and S-recycling at UB and LB was not practical, advective transport of $\mathrm{SO}_{4}{ }^{2-}$ was likely more important than diffusion in these heavily bioturbated surface sediments.

\section{Bioturbation}

Sediment mixing by benthic macrofauna may vary seasonally in temperate marine sediments due to temporal variations in both temperature and organic $\mathrm{C}$ supply and the abundance and type of macrofauna (Kemp \& Boynton 1981, Martin \& Sayles 1987, Aller \& Aller 1992). Increased bioturbation facilitates increased aerobic and anaerobic microbial activity (Aller \& Yingst 1985, Berner \& Westrich 1985, Kristensen \& Blackburn 1987), nutrient regeneration (Cowen \& Boynton 1996, Cowan et al. 1996, Kemp et al. 1997), and reduced-S oxidation (Berner \& Westrich 1985, Aller \& Rude 1988). The generally vertical SR depth profiles at UB and LB through the year (Fig. 2) in part reflect bioturbation, as this process homogenizes the active SR zone and partially mitigates $\mathrm{SO}_{4}{ }^{2-}$ limitation. This is in contrast to the essentially non-bioturbated MB site, where SR profiles exhibit much larger monthly changes. While not examined quantitatively in the current study, we believe bioturbation was most intense during summer at Sites UB and LB, based on high temperature, adequate $\mathrm{C}$ deposition, and macrofauna abundance. In Great Bay Estuary (NH), a significant increase in bioturbation activity was noted in May to June when bottom water temperatures exceeded $15^{\circ} \mathrm{C}$ (Hines et al. 1982). This increased macrofauna activity was followed by a tripling in the SR rate. Since maximum SR rates in the current study were observed during summer and fall at UB and LB (Table 1), we conclude that bioturbation was a factor in stimulating microbial rates at these sites. At MB, it appears that seasonal variation in SR has a stronger impact on macrobenthic community metabolism than the reverse. Bivalve spat typically colonize MB sediments during early spring, when $\mathrm{SR}$ rates are at their annual minimum and $\mathrm{H}_{2} \mathrm{~S}$ tends not to penetrate the sediment-water interface (Fig. $6 \mathrm{~m})$. With increasing temperature and sulfide flux across the sediment-water interface, these organisms are generally killed by early summer (Kemp et al. 2000, USACE 2000). 


\section{Organic carbon}

Both the quantity and quality of deposited organic matter can influence benthic anaerobic metabolism (Goldhaber \& Kaplan 1975, Kelly \& S.W. 1984, Westrich \& Berner 1984, Sampou \& Oviatt 1991, MarvinDiPasquale \& Capone 1998). The chl $a$ and PC:PN data (Fig. 6e,j) support earlier findings that indicate organic deposition to upper Bay sediments is refractory terrestrial material, while $\mathrm{MB}$ and LB sediments receive more labile phytoplankton detritus (Marvin-DiPasquale \& Capone 1998, Canuel \& Zimmerman 1999). Spring bloom deposition at MB and LB was indicated by peak chl a concentration in surface sediment during May, and spring was the only season during which organic parameters (chl $a$ and TOM) alone exhibited significant correlations with $\mathrm{SR}_{2}$ (Table 3), suggesting the linkage between phytoplankton deposition and the rapid response of SR at the sediment surface. However, the fact that $>75 \%$ of the variability in spring and fall $\mathrm{MB} \mathrm{SR}_{2}$ rates (or $\geq 30 \%$ for the Year grouping) could be explained by temperature and PC (or PN) combined (Table 4) indicates that $\mathrm{SR}$ in the mesohaline region of the Bay is generally very responsive to variations in organic input. While seasonal relationships between $\mathrm{SR}_{2}$ and organic quality (as PC:PN) were not detected, the general influence of organic quality on the SR-temperature relationship was evident, as the sites that receive primarily autochthonous C (i.e. MB and LB) had higher rates of SR overall compared to UB (Figs. $2 \& 3$ ). We conclude that the influence of organic loading on surface sediment SR rates was most important during spring at $\mathrm{MB}$ and $\mathrm{LB}$, and resulted from fresh phytoplankton deposition.

\section{Interannual variation in summertime sulfate reduction rates}

Interannual variation in the fluvial input of nutrients to the Chesapeake Bay directly affects the magnitude of annual primary production and benthic nutrient recycling (Malone et al. 1986, 1988, Kemp et al. 1999). We initially hypothesized that inter-annual variations in peak SR rates are similarly linked to inter-annual variations in the timing, duration, and magnitude of freshwater flow to the estuary. During high-flow years, increased primary production should lead to increased deposition of labile phytoplankton detritus, and subsequently to increased benthic SR rates, relative to low-flow years. A second hypothesis was that the magnitude of peak SR rates reflects the magnitude of the previous year's deposition. This type of temporal sediment 'memory' response has been suggested with respect to nutrient regeneration dynamics in the Chesapeake Bay (Boynton et al. 1982).
The positive relationship between $\mathrm{SR}_{2}$ and river flow at both UB and MB (Fig. 9) support the original hypothesis. However, the fact that the UB relationship was heavily weighted by a single year indicates that for the oligohaline portion of the estuary the effect of river flow on bethic SR is most pronounced in high-flow years (e.g. 1993) and less of a factor during low- to moderate-flow years. The positive response of $\mathrm{SR}_{2}$ to increasing river flow was more continuously distributed at $M B$, reflecting the fact that the mesohaline deep channel is a major focal point of deposition for phytoplankton produced bay-wide, including from the (1) oligohaline via down-estuary surface water transport (Biggs \& Flemer 1972), (2) overlying water column, (3) shallow mesohaline flanks via lateral transport (Malone et al. 1986), and (4) polyhaline via up-estuary bottom water transport (Tyler \& Seliger 1978, Malone et al. 1988). Hence, the mesohaline portion of the Bay is a better integrator of the effect of interannual fluctuations in river flow on net primary production than is the oligohaline region. Interannual variation in July $\mathrm{SR}_{2}$ rates at $\mathrm{MB}$ appears to be most responsive to the cumulative input of organic matter throughout the late-winter to early summer period, as the best relationship was found only when a very wide time averaged river flow window was used (February to June). While the highest average monthly flow occurred in April 1993, the second highest was of longer duration and occurred 1 mo earlier (March to April 1994) (Fig. 8). Of these 2 years, July MB SR 2 was highest in 1994. However, water column data collected as part of the LMER study suggests that the exceptionally large 1993 freshet may have pushed the majority of the phytoplankton bloom biomass south of Site MB, which may explain the lower $\mathrm{SR}_{2}$ rates in 1993 compared with 1994 (Fig. 9).

The negative relationship between $\mathrm{SR}_{2}$ and river flow at LB was not predicted by our original hypothesis. We subsequently propose that this trend resulted from up-estuary transport of spring algal bloom biomass. Due to the Bay's 2-layer circulation pattern, as freshwater flows seaward at the surface, return-flow high-salinity bottom water moves up the estuary (Schubel \& Pritchard 1987). This hydrology is responsible for the up-estuary transport of phytoplankton in bottom waters, produced in the lower Chesapeake Bay surface waters during spring. The volume of bottom-water return flow at the Bay mouth is roughly $10 \times$ the Susquehanna River outflow (Day et al. 1989). Hence, the larger the spring freshet, the greater the up-estuary flow velocity, and the larger the fraction of sinking biomass transported away from the lower Bay region of production. As the effect of up-estuary transport decreases with distance from the Bay mouth, an increased fraction of sus- 
pended particulate matter is deposited to the benthos. Zimmerman \& Canuel (2001) recently reported that a high spring flow year for the Susquehanna River resulted in increased fresh algal-derived organic matter in mesohaline surface sediments that same year, but not in lower Bay sediments. These findings are in agreement with our current conclusions. When the average river-flow time window included data from the previous fall (October to December), no regressions were significant at any site. A SR response to some sediment 'memory' of stored labile $\mathrm{C}$ from the previous year's deposition was therefore not implied.

\section{Implications with respect to bottom-water anoxia}

As a dominant microbial process in estuaries, sulfate reduction impacts a number of related ecosystem processes, including the net remineralization of fixed carbon, the biogeochemical cycling of sulfur, the cycling of iron and manganese via the formation of metal-sulfide minerals, and the consumption of dissolved oxygen linked to the reoxidation of reduced-S end-products. The latter process is largely responsible for bottom water hypoxia/anoxia in Chesapeake Bay (Roden \& Tuttle 1992), which is ultimately driven by system eutrophication leading to enhanced autochthonous production and enhanced microbial respiration. Hypoxia/anoxia has long been recognized as a problem in this and other estuaries (Seliger et al. 1985, Summers et al. 1997), as low dissolved oxygen conditions have negative repercussions, both aesthetically and with respect to the survival of estuarine biota (Holland 1985, Breitburg et al. 1997). The current study illustrates how the interaction of multiple biogeochemical and physical factors ultimately control the response of estuarine SR on multiple temporal scales (months, seasons and years), and how these temporal responses vary for different regions of the system. Of particular significance are the findings that the magnitude of the spring river flow influenced that year's summertime SR rates, and that there was a correlation between the quantity of phytoplankton detritus (as chl a) and SR rates in surface sediments during spring in the meso- and polyhaline portions of the estuary. Both observations support the hypothesis that there is a tight coupling between benthic SR rates and the amount of phytoplankton biomass deposited to the benthos. Hence, the ecosystem benefits from management practices that limit the input of inorganic nutrients, and subsequently limit the low oxygen conditions driven by enhanced SR, which may be realized on timescales as short as years, as opposed to decades.
Acknowledgements. The authors thank K. Warner, E. Roden, J. Burns, G. Yellin, C. Shoemaker, E. Smith, J. Barnes, D. Jasinski, V. Miller, M. Wolf, J. Nelson, S. Jenkins, T. Haas, M. Thomas and the captains and crews of RVs 'Cape Henelopen' and 'Ridgley Warfield' for field and laboratory assistance. This research was supported by National Science Foundation Grants BSR-8814272 and DEB-8814272 (both awarded, in part, to D.G.C. and W.R.B.), and was conducted as part of M.C.M.-D.'s graduate program at the University of Maryland, Chesapeake Biological Laboratory (Solomons, Maryland).

\section{LITERATURE CITED}

Abdollahi H, Nedwell DB (1979) Seasonal temperature as a factor influencing bacterial sulfate reduction in a salt marsh. Microb Ecol 5:73-79

Ahmed SI, Williams BL, Johnson V (1992) Microbial populations isolated from the sediments of an anoxic fjord: an examination of fermentative bacteria involved in organic matter diagenesis in Saanich Inlet, B.C., Canada. Mar Microb Food Webs 6:133-148

Aller RC, Aller JY (1992) Meiofauna and solute transport in marine muds. Limnol Oceanogr 37:1018-1033

Aller RC, Aller JY (1998) The effect of biogenic irrigation intensity and solute exchange on diagenetic reaction rates in marine sediments. J Mar Res 56:905-936

Aller RC, Rude PD (1988) Complete oxidation of solid phase sulfides by manganese and bacteria in anoxic marine sediments. Geochim Cosmochim Acta 52:751-765

Aller RC, Yingst JY (1985) Effects of the marine deposit feeders Heteromastus filiformis (Polychaeta), Macoma balthica (Bivalvia), and Tellina texana (Bivalvia) on averaged sedimentary solute transport, reaction rates, and microbial distributions. J Mar Res 43:615-645

Berner RA (1978) Sulfate reduction and the rate of deposition of marine sediments. Earth Planet. Sci Let 37:492-498

Berner RA (1980) Early diagenesis - a theoretical approach. Princeton University Press, Princeton, NJ

Berner RA, Westrich JT (1985) Bioturbation and the early diagenesis of carbon and sulfur. Am J Sci 285:193-206

Biggs RB, Flemer DA (1972) The flux of particulate carbon in an estuary. Mar Biol 12:11-17

Boudreau BP, Westrich JT (1984) The dependence of bacterial sulfate reduction on sulfate concentration in marine sediments. Geochim Cosmochim Acta 48:2503-2516

Boynton WR, Kemp WM, Keefe CW (1982) A comparative analysis of nutrients and other factors influencing estuarine phytoplankton production. In: Kennedy VS (ed) Estuarine comparisons. Academic Press, New York, p 69-90

Breitburg DL, Loher T, Pacey CA, Gerstein A (1997) Varying effects of low dissolved oxygen on trophic interactions in an estuarine food web. Ecol Monogr 67:489-507

Canuel EA, Zimmerman AR (1999) Composition of particulate organic matter in the southern Chesapeake Bay: sources and reactivity. Estuaries 22:980-994

Capone DG, Kiene RP (1988) Comparison of microbial dynamics in marine and freshwater sediments: contrasts in anaerobic carbon catabolism. Limnol Oceanogr 33:725-749

Cline JD (1969) Spectrophotometric determination of hydrogen sulfide in natural waters. Limnol Oceanogr 14:454-458

Cowen JLW, Boynton WR (1996) Sediment-water oxygen and nutrient exchanges along the longitudinal axis of Chesapeake Bay: seasonal patterns, controlling factors and ecological significance. Estuaries 19:562-580

Cowan JLW, Pennock JR, Boynton WR (1996) Seasonal and 
interannual patterns of sediment-water nutrient and oxygen fluxes in Mobile Bay, Alabama (USA): regulating factors and ecological significance. Mar Ecol Prog Ser 141: 229-245

Crill PM, Martens CS (1987) Biogoechemical cycling in an organic-rich coastal marine basin. 6. Temporal and spatial variations in sulfate reductions rates. Geochim Cosmochim Acta 51:1175-1186

Day JW, Hall CAS, Kemp WM, Yàñez-Arancibia A (1989) Estuarine ecology. John Wiley \& Sons, New York

Goldhaber MB, Kaplan IR (1975) Controls and consequences of sulfate reduction rates in recent marine sediments. Soil Sci 119:42-55

Hines ME, Jones GE (1985) Microbial biogeochemistry and bioturbation in the sediments of Great Bay, New Hampshire. Estuar Coast Shelf Sci 20:729-742

Hines ME, Lyons WB (1982) Biogeochemistry of nearshore Bermuda sediments. I. Sulfate reduction rates and nutrient generation. Mar Ecol Prog Ser 8:87-94

Hines ME, Orem WH, Lyons WB, Jones GE (1982) Microbial activity and bioturbation-induced oscillations in pore water chemistry of estuarine sediments in spring. Nature 299:433-435

Holland AF (1985) Long-term variation of macrobenthos in a mesohaline region of Chesapeake Bay. Estuaries 8:93-113

Jørgensen BB (1977) The sulfur cycle of a coastal marine sediment (Limfjorden, Denmark). Limnol Oceanogr 22: 814-832

Jørgensen BB (1978a) A comparison of methods for the quantification of bacterial sulfate reduction in coastal marine sediments. 1. Measurement with radiotracer techniques. Geomicrobiol J 1:11-28

Jørgensen BB (1978b) A comparison of methods for the quantification of bacterial sulfate reduction in coastal marine sediments. 2. Calculations from mathematical models. Geomicrobiol J 1:29-51

Jørgensen BB (1990a) The sulfur cycle of freshwater sediments: role of thiosulfate. Limnol Oceanogr 35:1329-1342

Jørgensen BB (1990b) A thiosulfate shunt in the sulfur cycle of marine sediments. Science 249:152-154

Kelly JR, Nixon SW (1984) Experimental studies of the effect of organic deposition on the metabolism of a coastal marine bottom community. Mar Ecol Prog Ser 17:157-169

Kemp WM, Boynton WR (1981) External and internal factors regulating metabolic rates of an estuartine benthic community. Oecologia 51:19-27

Kemp WM, Smith EM, Marvin-DiPasquale M, Boynton WR (1997) Organic carbon balance and net ecosystem metabolism in Chesapeake Bay. Mar Ecol Prog Ser 150:229-248

Kemp WM, Faganeli J, Puskaric S, Smith EM, Boynton WR (1999) Pelagic-benthic coupling and nutrient cycling. In: Malone TC, Malej A, Harding LW Jr, Smodlaka N, Turner RE (eds) Ecosystems at the land-sea margin: drainage basin to coastal sea. Coastal and estuarine studies, Vol 55. American Geophysical Union, Washington, DC, p 295-339

Kemp WM, Bartleson R, Blumenshine S, Hagy JD, Boynton WR (2000) Ecosystem models of the Chesapeake Bay relating nutrient loadings, environmental conditions, and living resources. Chesapeake Bay Program Office. Annapolis, MD, also available at www.chesapeakebay. net/pubs/1363.pdf

King GM (1988) Patterns of sulfate reduction and the sulfur cycle in a South Carolina salt marsh. Limnol Oceanogr 33: 376-390

Kristensen E, Blackburn TH (1987) The fate of organic carbon and nitrogen in experimental marine sediment systems: in- fluence of bioturbation and anoxia. J Mar Res 45:231-257

Krom MD, Berner RA (1980) The diffusion coefficients of sulfate, ammonium, and phosphate ions in anoxic marine sediments. Limnol Oceanogr 25:327-337

Li YH, Gregory S (1974) Diffusion of ions in sea water and in deep-sea sediments. Geochim Cosmochim Acta 38: 703-714

Lovley DR, Phillips EJP (1994) Novel processes for anaerobic sulfate production from elemental sulfur by sulfatereducing bacteria. Appl Environ Microbiol 60:2394-2399

Malone TC, Kemp WM, Ducklow HW, Boynton WR, Tuttle $\mathrm{JH}$, Jonas RB (1986) Lateral variation in the production and fate of phytoplankton in a partially stratified estuary. Mar Ecol Prog Ser 32:149-160

Malone TC, Crocker LH, Pike SE, Wendler BW (1988) Influence of river flow on the dynamics of phytoplankton production in a partially stratified estuary. Mar Ecol Prog Ser 48:235-249

Martens CS, Klump JV (1984) Biogeochemical cycling in an organic-rich coastal marine basin. 4. An organic carbon budget for sediments dominated by sulfate reduction and methanogenesis. Geochim Cosmochim Acta 48:1987-2004

Martin WR, Sayles FL (1987) Seasonal cycles of particle and solute transport processes in nearshore sediments: 222Rn/ 226Ra and 234Th/238U disequilibrium at a site in Buzzards Bay, MA. Geochim Cosmochim Acta 51:927-943

Marvin-DiPasquale MC, Capone DG (1998) Benthic sulfate reduction along the Chesapeake Bay central channel. I. Spatial trends and controls. Mar Ecol Prog Ser 168:213-228

Matisoff G (1980) Time dependent transport in Chesapeake Bay sediments. Part I. Temperature and chloride. Am J Sci 280:1-25

Moeslund L, Thamdrup B, Jørgensen BB (1994) Sulfur and iron cycling in a coastal sediment: radiotracer studies and seasonal dynamics. Biogeochemistry 27:129-152

Roden EE, Tuttle JH (1992) Sulfide release from estuarine sediments underlying anoxic bottom water. Limnol Oceanogr $37: 725-738$

Roden EE, Tuttle JH (1993a) Inorganic sulfur cycling in mid and lower Chesapeake Bay sediments. Mar Ecol Prog Ser 93:101-118

Roden EE, Tuttle JH (1993b) Inorganic sulfur turnover in oligohaline estuarine sediments. Biogeochemistry 22:81-105

Sampou P, Oviatt CA (1991) Seasonal patterns of sedimentary carbon and anaerobic respiration along a simulated eutrophication gradient. Mar Ecol Prog Ser 72:271-282

Schaffner LC (1990) Small-scale organism distributions and patterns of species diversity: evidence for positive interactions in an estuarine benthic community. Mar Ecol Prog Ser 61:107-117

Schubel JR, Pritchard DW (1987) A brief physical description of the Chesapeake Bay. In: Majumdar SK, Hall LW Jr, Austin HM (eds) Contaminant problems and management of living Chesapeake Bay resources. The Pennsylvania Academy of Sciences, Easton, PA, p 1-32

Seliger HH, Biggs JA, Biggley WH (1985) Catastrophic anoxia in the Chesapeake Bay in 1984. Science 228:70-73

Sherman LA, Baker LA, Weir EP, Brezonik PL (1994) Sediment pore-water dynamics of Little Rock Lake, Wisconsin: geochemical processes and seasonal and spatial variability. Limnol Oceanogr 39:1155-1171

Shiah FK, Ducklow HW (1994) Temperature regulation of heterotrophic bacterioplankton abundance, production, and specific growth rate in Chesapeake Bay. Limnol Oceanogr 39:1243-1258

Skyring GW (1987) Sulfate reduction in coastal ecosystems. Geomicrobiol J 5:295-374 
Smith EM, Kemp WM (1995) Seasonal and regional variations in plankton community production and respiration for Chesapeake Bay. Mar Ecol Prog Ser 116:217-231

Smith EM, Kemp WM (2001) Size structure and the production/respiration balance in a coastal plankton community. Limnol Oceanogr 46:473-485

Strickland JDH, Parsons TR (1972) A practical handbook of seawater analysis. Fisheries Research Board of Canada, Ottawa

Summers JK, Weisberg SB, Holland AF, Kou JY, Engle VD, Breitberg DL, Diaz RJ (1997) Characterizing dissolved oxygen conditions in estuarine environments. Environ Monit Assess 45:319-328

Thamdrup B, Finster K, Hansen JW, Bak F (1993) Bacterial disproportionation of elemental sulfur coupled to chemical reduction of iron or manganese. Appl Environ Microbiol 59:101-108

Turekian KK (1968) Oceans. Prentice-Hall, Englewood Cliffs, NJ

Tyler MA, Seliger HH (1978) Annual subsurface transport of a red tide dinoflagellate to its bloom area: water circulation

Editorial responsibility: Evelyn \& Barry Sherr (Contributing Editors), Corvallis, Oregon, USA patterns and organism distributions in the Chesapeake Bay. Limnol Oceanogr 23:227-246

Urban NR, Brezonik PL, Baker LA, Sherman LA (1994) Sulfate reduction and diffusion in sediments of Little Rock Lake, Wisconson. Limnol Oceanogr 39:797-815

USACE (US Army Corps of Engineers) (2000) Development of a suspension feeding and deposit feeding benthos model for Chesapeake Bay. USACE, available at www.chesapeakebay.net/pubs/subcommittee/mdsc/hqi_benthos_model. pdf

USGS (US Geological Survey) (1987-1994) Susquehanna River Discharge data at Conowingo Dam, MD: continuous monitoring database of estimated streamflow entering the Chesapeake Bay. USGS, Towson, MD

Westrich JT, Berner RA (1984) The role of sedimentary organic matter in bacterial sulfate reduction: the $\mathrm{G}$ model tested. Limnol Oceanogr 29:236-249

Zimmerman AR, Canuel EA (2001) Bulk organic matter and lipid biomarker composition of Chesapeake Bay surficial sediments as indicators of environmental processes. Estuar Coastal Shelf Sci 53:319-341

Submitted: December 2, 2002; Accepted: June 4, 2003 Proofs received from author(s): September 3, 2003 